\title{
Sodium Channel $\beta 2$ Subunits Prevent Action Potential Propagation Failures at Axonal Branch Points
}

\author{
In Ha Cho, $\$ Lauren C. Panzera, Morven Chin, and Michael B. Hoppa \\ Department of Biological Sciences, Dartmouth College, Hanover, New Hampshire 03755
}

\begin{abstract}
Neurotransmitter release depends on voltage-gated $\mathrm{Na}^{+}$channels $\left(\mathrm{Na}_{\mathrm{v}} \mathrm{s}\right)$ to propagate an action potential (AP) successfully from the axon hillock to a synaptic terminal. Unmyelinated sections of axon are very diverse structures encompassing branch points and numerous presynaptic terminals with undefined molecular partners of $\mathrm{Na}^{+}$channels. Using optical recordings of $\mathrm{Ca}^{2+}$ and membrane voltage, we demonstrate here that $\mathrm{Na}^{+}$channel $\beta 2$ subunits $\left(\mathrm{Na}_{\mathrm{v}} \beta 2 \mathrm{~s}\right)$ are required to prevent AP propagation failures across the axonal arborization of cultured rat hippocampal neurons (mixed male and female). When $\mathrm{Na}_{\mathrm{v}} \beta 2$ expression was reduced, we identified two specific phenotypes: (1) membrane excitability and AP-evoked $\mathrm{Ca}^{2+}$ entry were impaired at synapses and (2) AP propagation was severely compromised with $>40 \%$ of axonal branches no longer responding to AP-stimulation. We went on to show that a great deal of electrical signaling heterogeneity exists in AP waveforms across the axonal arborization independent of axon morphology. Therefore, $\mathrm{Na}_{\mathrm{v}} \beta 2$ is a critical regulator of axonal excitability and synaptic function in unmyelinated axons.
\end{abstract}

Key words: action potential; axon; beta2 subunit; sodium channel; synapse; unmyelinated

Significance Statement

Voltage-gated $\mathrm{Ca}^{2+}$ channels are fulcrums of neurotransmission that convert electrical inputs into chemical outputs in the form of vesicle fusion at synaptic terminals. However, the role of the electrical signal, the presynaptic action potential (AP), in modulating synaptic transmission is less clear. What is the fidelity of a propagating AP waveform in the axon and what molecules shape it throughout the axonal arborization? Our work identifies several new features of AP propagation in unmyelinated axons: (1) branches of a single axonal arborization have variable AP waveforms independent of morphology, (2) $\mathrm{Na}^{+}$channel $\beta 2$ subunits modulate AP-evoked $\mathrm{Ca}^{2+}$-influx, and (3) $\beta 2$ subunits maintain successful AP propagation across the axonal arbor. These findings are relevant to understanding the flow of excitation in the brain.

\section{Introduction}

The cycle of synaptic transmission is set in motion by an action potential (AP) invading the presynaptic terminal (Lisman et al., 2007). Although individual synapses along an axon can have substantially different responses in vesicle release probability and $\mathrm{Ca}^{2+}$ influx (Rosenmund et al., 1993; Koester and Sakmann, 2000; Ariel et al., 2012; Ermolyuk et al., 2012), the AP is often

\footnotetext{
Received April 2, 2017; revised Aug. 21, 2017; accepted Aug. 22, 2017.

Author contributions: I.H.C. and M.B.H. designed research; I.H.C., L.C.P., M.C., and M.B.H. performed research; I.H.C., L.C.P., M.C., and M.B.H. analyzed data; I.H.C. and M.B.H. wrote the paper.

This work was supported by the Brain Research Foundation (Grant BRFSF_2015-05) and the American Cancer Society (Grant IRG-82-003-33). We thank Hoppa Laboratory members S.A. Alpizar and R.J. 0'Toole for helpful contributions; Timothy Ryan (Weill Cornell Medical College) and Allan Gulledge (Dartmouth Geisel School of Medicine) for useful discussions; Linlin Fan and Adam Cohen (Harvard University) for assistance in obtaining electrophysiological recordings; Justin Taraska for contributing INS-1 cells for Western blotting experiments; and Nobuyuki Nukina (Doshisha University) for sharing $\mathrm{Na}_{\mathrm{v}} \beta$ antibodies.

The authors declare no competing financial interests.

Correspondence should be addressed to Dr. Michael Hoppa, Department of Biological Sciences, Class of 1978 Life Sciences Center, 78 College Street, Room 345, Hanover, NH 03755. E-mail: michael.b.hoppa@dartmouth.edu.

D0I:10.1523/JNEUROSCI.0891-17.2017

Copyright $\odot 2017$ the authors $\quad 0270-6474 / 17 / 379519-15 \$ 15.00 / 0$
}

ignored as a source of this variability because of its perception as a uniform "all-or-none" signal. In essence, the AP waveform is a command signal that forces closed voltage-gated $\mathrm{Ca}^{2+}$ channels $\left(\mathrm{Ca}_{\mathrm{v}} \mathrm{s}\right)$ through a series of conformational transitions to their open state, a process that is steeply dependent on membrane voltage $\left(V_{\mathrm{m}}\right)$ (Li et al., 2007). At the same time, vesicle fusion is also a supralinear process that is steeply dependent (by a thirdfourth order power-law) on $\mathrm{Ca}^{2+}$ entry at the synapse (Dodge and Rahamimoff, 1967; Augustine et al., 1985). Therefore, the AP shape can exert enormous impact on neurotransmission (Siegelbaum et al., 1982; Sabatini and Regehr, 1997; Borst and Sakmann, 1999; Bischofberger et al., 2002; Rama et al., 2015).

Much of what we know about AP shape in mammalian neurons has come from whole-cell recordings, with few recordings from axons or synaptic terminals due to their fine structure (Bean, 2007). Recent optical measurements of the axonal AP demonstrated localized voltage-gated $\mathrm{K}^{+}$channel $\left(\mathrm{K}_{\mathrm{v}}\right)$ activity between presynaptic terminals of cerebellar stellate cells (Rowan et al., 2014; Rowan et al., 2016). In addition, subcellular heterogeneities in axonal voltage-gated $\mathrm{Na}^{+}$channel $\left(\mathrm{Na}_{\mathrm{v}}\right)$ enrichment 
between the axon and synapse has been demonstrated in inhibitory basket cells (Hu and Jonas, 2014), the calyx of Held (Leão et al., 2005), and Purkinje cells (Kawaguchi and Sakaba, 2015). Together, these results suggest that AP shape and membrane excitability may in some cases be controlled locally within discrete sections of the axon and/or synaptic terminals. However, the mechanism(s) that defines local excitability and ion channel function has yet to be determined for unmyelinated axons.

In terms of successful AP propagation, $\mathrm{Na}_{\mathrm{v}} \mathrm{s}$ are the critical drivers for active conduction. In the brain, $\mathrm{Na}_{\mathrm{v}} \mathrm{s}$ are often found as complexes between the pore-forming $\alpha$-subunit and transmembrane $\beta$-subunits (Hartshorne et al., 1982; Isom et al., 1994; Yu et al., 2003; Namadurai et al., 2015). $\mathrm{Na}^{+}$channel $\beta 2$ subunits $\left(\mathrm{Na}_{\mathrm{v}} \beta 2 \mathrm{~s}\right)$ have been shown to regulate membrane trafficking of the pore-forming $\alpha$ subunit $\left(\mathrm{Na}_{\mathrm{v}} \alpha\right)$, with acutely isolated somata from the hippocampus of $\mathrm{Na}_{\mathrm{v}} \beta 2$-null mice displaying a $\sim 50 \%$ reduction in $\mathrm{Na}^{+}$current density (Isom et al., 1995; Chen et al., 2002). In addition, the integral of compound APs recorded from optic nerved bundles was also reduced, demonstrating a role for $\mathrm{Na}_{\mathrm{v}} \beta 2$ to modulate $\mathrm{Na}_{\mathrm{v}}$ density in the myelinated axon (Chen et al., 2002). Interestingly, $\mathrm{Na}_{\mathrm{V}} \beta 2$-null mice display a resistance to neurodegeneration in an experimental model of multiple sclerosis, suggesting an important role for $\mathrm{Na}_{\mathrm{v}} \beta 2$ in demyelinated axons (O'Malley et al., 2009). As a result of these data, we hypothesized that $\mathrm{Na}_{\mathrm{v}} \beta 2$ may play a critical role in modulating the AP within normal unmyelinated sections of axon that form en passant synaptic terminals in many regions of the brain. We explore this hypothesis using a combination of genetically encoded $\mathrm{Ca}^{2+}$ and membrane voltage $\left(V_{\mathrm{m}}\right)$ indicators within single axonal arborizations in dissociated hippocampal neurons. First, we found that normal axons have a large degree of heterogeneity in the waveform throughout the axonal aborization that is independent of axon morphology. Second, we demonstrate that depletion of $\mathrm{Na}_{\mathrm{v}} \beta 2$ subunits impairs AP-evoked presynaptic $\mathrm{Ca}^{2+}$ influx. Third, we report that the $\mathrm{Na}_{\mathrm{v}} \beta 2$ subunit plays a critical role in maintaining AP propagation across axonal ramifications of excitatory hippocampal neurons. Together, our results point to a fundamental role for $\mathrm{Na}_{\mathrm{v}} \beta 2$ for controlling AP waveform fidelity in unmyelinated branches of axonal arborizations and an important role for branch points in axonal signaling beyond controlling the timing of synaptic transmission.

\section{Materials and Methods}

Cell culture. Hippocampal CA1-CA3 regions were dissected with dentate gyrus removed from postnatal day 1 Sprague Dawley rats of either sex (mixed litter), dissociated (bovine pancreas trypsin; $5 \mathrm{~min}$ at room temperature), and plated on polyornithine-coated coverslips inside a 6-mmdiameter cloning cylinder as described previously (Hoppa et al., 2012a). Calcium-phosphate-mediated transfection was performed on 5-d-old cultured neurons with the plasmids described below. All measurements, unless otherwise noted, are from mature 14- to 24-d-old neurons. Experiments with Sprague Dawley rats were approved by Dartmouth College's Institutional Animal Care and Use Committee. INS-1 cell lines (823/13, passage 47-50) were obtained from Dr. Justin Taraska (National Institutes of Health). INS-1 cells were cultured and transfected as described previously (Hoppa et al., 2012b).

Plasmids. SypGCaMP and $\alpha 2 \delta$ - 1 were obtained as described previously (Hoppa et al., 2012a) and QuasAr was acquired from Addgene (Plasmid 51692: FCK-QuasAr2-mO2). For knock-down of endogenous $\mathrm{Na}_{\mathrm{v}} \beta 2$ or $\mathrm{Na}_{\mathrm{v}} \beta 4$, prevalidated shRNA plasmids were purchased from Origene against the following mRNA target sequences: GCTATACCGTGAACCACAAGCAGTTCTCT and TACTTCAGGTGG TCCTACAATAACAGCGA, respectively. To confirm shRNA-mediated knock-down data, we inserted single-guide RNA (sgRNA) targeting $\mathrm{Na}_{\mathrm{v}} \beta 2$ (CACCGCCACTCTTAGTGTCCTCAAC) into pU6-(BbsI)CBh-
Cas9-T2A-mCherry plasmid purchased from Addgene (plasmid 64324). For expression of human $\mathrm{Na}_{\mathrm{v}} \beta 2$ (NM_004588.3, plasmid RC207778) to perform rescue experiments, we inserted both human $\mathrm{Na}_{\mathrm{v}} \beta 2$ fused to T2A peptide synthesized using GeneArt Gene Synthesis (Invitrogen) and SypGCaMP into pFCK plasmid, inducing independent expression of two different proteins in neurons. To measure $\mathrm{Ca}^{2+}$ influx and $V_{\mathrm{m}}$ in the same cell, we designed a DarkQuasAr-T2A-SypGCaMP construct. We inserted DarkQuasAr, which has a mutation in the mOrange sequence not to show any fluorescence (Y327A) before T2A-SypGCaMP, which is under the human Synapsin 1 promoter. We validated that DarkQuasAr and SypGCaMP were coexpressed in the same cells through many repetitive experiments.

Antibodies. Rabbit polyclonal anti- $\mathrm{Na}_{\mathrm{v}} \beta 2$ antibody was kindly provided by Dr. Nobuyuki Nukina (Miyazaki et al., 2014). Mouse monoclonal antibodies were used against $\mathrm{Na}_{\mathrm{v}} 1.2$ and GFP (Neuromab), pan-sodium channel and $\alpha$-Tubulin (Sigma-Aldrich), and PSD-95 (Thermo Fisher Scientific). Rabbit polyclonal $\mathrm{Na}_{\mathrm{v}} 1.6$ and chicken polyclonal GFP-tag antibody were purchased from Millipore and Invitrogen, respectively. Alexa Fluor 488-, 546-, and 647-conjugated goat antirabbit, anti-mouse, and anti-chicken IgG and horseradish peroxidaseconjugated anti-mouse and anti-rabbit IgG were from Invitrogen.

Live-cell imaging and optical setup. All experiments were performed at $34^{\circ} \mathrm{C}$ using a custom-built objective heater. Coverslips were mounted in a rapid-switching, laminar-flow perfusion and stimulation chamber on the stage of a custom-built laser microscope. The total volume of the chamber was $\sim 75 \mu \mathrm{l}$ and was perfused at a rate of $400 \mu \mathrm{l} / \mathrm{min}$. During imaging, cells were perfused continuously in a standard saline solution containing the following (in $\mathrm{mm}$ ): $119 \mathrm{NaCl}, 2.5 \mathrm{KCl}, 2 \mathrm{CaCl}_{2}, 2 \mathrm{MgCl}_{2}$, 25 HEPES, and 30 glucose plus $10 \mu \mathrm{M}$ 6-cyano-7-nitroquinoxaline-2,3dione (Sigma-Aldrich) and $50 \mu \mathrm{M}$ D,L-2-amino-5-phosphonovaleric acid (Sigma-Aldrich). For high $\mathrm{K}^{+}$solution experiments, cells were perfused in a modified solution with equimolar substitution to create a 90 mM KCl concentration. Tetrodotoxin (TTX) was made at a stock concentration of $3 \mathrm{~mm}$ and used at different diluted concentrations (Alomone Laboratories).

For measuring $\mathrm{Ca}^{2+}$ influx, specimens of SypGCaMP-transfected neurons were illuminated by a $488 \mathrm{~nm}$ laser $6-8 \mathrm{~mW}$ (Coherent OBIS laser) with ZET488/10x and ZT488rdc dichroic (Chroma) through a Zeiss EC Plan-Neofluar $40 \times 1.3$ numerical aperture (NA) objective. SypGCaMP florescent emission was collected through an ET525/50m filter (Chroma) and captured with an IXON Ultra 897 EMCCD (Andor). SypGCaMP fluorescence was collected with an exposure time of $9.83 \mathrm{~ms}$ and images were acquired at $100 \mathrm{~Hz}$.

For the measurement of APs, specimens of QuasAr-transfected neurons were illuminated by a $637 \mathrm{~nm}$ laser $50-92 \mathrm{~mW}$ (depending on imaging soma vs axon, respectively; Coherent OBIS laser) with ET620/60 excitation filters and a 660 long-pass dichroic with an ET700/75 emission filter all purchased from Chroma. Light was collected through a Zeiss EC Plan-Neofluar $40 \times 1.3$ NA objective using a cropped sensor mode $(10$ $\mathrm{MHz}$ readout, $500 \mathrm{~ns}$ pixel shift speed) to achieve $2 \mathrm{kHz}$ frame rate imaging (exposure time of $485 \mu \mathrm{s}$ ) using an intermediate image plane mask (Optomask; Cairn Research) to prevent light exposure of nonrelevant pixels as described previously (Hoppa et al., 2014). The camera was cooled using an EXOS liquid cooling system (Koolance). For simultaneous measurements of somatic voltage under patch-clamp conditions, experiments were performed as described previously (Kralj et al., 2011) except using $2 \mathrm{kHz}$ acquisition.

For measuring axon and bouton diameter, experiments were performed on a Zeiss LSM 880 with Airyscan at $34^{\circ} \mathrm{C}$. SypGCaMP imaging was performed on a $40 \times 1.3 \mathrm{NA}$ objective by confocal imaging for detecting where branch point failure happened by TTX treatment. SypGCaMP fluorescence images were acquired at $5 \mathrm{~Hz}$. Subsequently, mOrange signal from QuasAr was taken on a $100 \times 1.46$ NA objective by Airyscan imaging to measure axon and bouton diameter. Airyscan images were zoomed at $1.8-2.3 \times$ and $z$ sections were taken at $0.18 \mu \mathrm{m}$ intervals. Image analysis of axon and bouton diameter was performed blinded and independently (see below). 
Stimulus control. APs were evoked by passing $1 \mathrm{~ms}$ current pulses, yielding fields of $\sim 12 \mathrm{Vcm}^{-2}$ (unless otherwise noted) through the chamber via platinum/iridium electrodes. Unless otherwise noted, trial averages of AP waveforms were derived from 100 stimuli delivered at $\sim 8$ Hz. For averaging across many trials in QuasAr recordings, the stimulus was locked to defined frame number intervals using a custom-built board named "Neurosync" powered by an Arduino Duo chip manufactured by an engineering firm (Sensorstar).

Immunofluorescence. To measure the $\mathrm{Na}_{\mathrm{v}} \beta 2$ shRNA and sgRNA efficiency, neurons were visualized at $14-17 \mathrm{~d}$ in vitro (DIV). Cells were fixed with $4 \%$ paraformaldehyde and $4 \%$ sucrose in PBS and permeabilized with $10 \%$ Triton X-100 and $10 \%$ goat serum in PBS for $30 \mathrm{~min}$, which helped to visualize $\mathrm{Na}_{\mathrm{v}}$ localization at the axon initial segment (Akin et al., 2015). Cells were then incubated with the appropriate primary antibodies and visualized using Alexa Fluor-conjugated secondary antibodies in the $5 \%$ goat serum in PBS. Images were obtained using a custom-made fluorescence microscope equipped with $40 \times$ oil-immersion objectives.

Western blotting assay. Hippocampal neurons at DIV 7 and DIV 14 and INS- 1 cell lines were washed with cold PBS twice and extracted for $1 \mathrm{~h}$ at $4^{\circ} \mathrm{C}$ in radioimmunoprecipitation assay (RIPA) buffer containing $50 \mathrm{~mm}$ Tris, $\mathrm{pH}$ 8.0, $150 \mathrm{~mm} \mathrm{NaCl}, 1 \%$ Nonidet P-40 (NP-40), 0.5\% sodium deoxycholate, and $0.1 \%$ SDS supplemented with protease inhibitors (Sigma-Aldrich). The extracts were then clarified by centrifugation for $10 \mathrm{~min}$ at $13000 \mathrm{rcf}$ and the protein concentrations in the supernatants were determined using bicinchoninic acid assays (Thermo Fisher Scientific). The resultant extracts were separated by SDS-PAGE and transferred onto PVDF membranes. The membranes were then blocked with $5 \%$ skim milk in buffer containing $10 \mathrm{~mm}$ Tris- $\mathrm{HCl}, \mathrm{pH}$ 7.5, $100 \mathrm{~mm}$ $\mathrm{NaCl}$, and $0.1 \%$ Tween 20 . Once blocked, the membranes were probed with primary antibodies followed by horseradish peroxidase-conjugated antibody (Invitrogen) and the blots were detected using enhanced chemiluminescence reagent (Thermo Fisher Scientific) on a Bio-Rad Chemidoc MP and accompanying software was used for quantification of imaged bands.

Experimental design and statistical analysis. Before measurement of QuasAr based on a priori knowledge of the signal-to-noise ratio, we determined that, to identify a change of $20 \%$ in signal across genetic deletion conditions would require $n=8$ dishes. This value was calculated using a power analysis $(\alpha=0.05, \beta=0.80)$ for a K-sample means one-way ANOVA. For all experimental conditions, hippocampi from both genders of rat pups were mixed before digestion and culture. A minimum of three separate cultures were used for experimentation. The comparison of means for two independent distributions was performed with the two-sample $t$ test given that the data were normally distributed. In many cases, where more than two groups were compared, a one-way ANOVA followed by Tukey's post hoc comparison was calculated to determine statistical significance using OriginPro version 9.1. The use of these tests is specified in the Results and figure legends for clarity. The analysis of axon morphology was performed blinded (as detailed in the "Image and data analysis" section below).

Image and data analysis. Images were analyzed in Image J using custom-written plugins (http://rsb.info.nih.gov/ij/plugins/time-series. $\mathrm{html})$. Averaged data are presented as means $\pm \operatorname{SEM}(n=$ number of neurons) and all experiments were performed on more than three independent cultures from different litters. $\Delta F / F$ values of the $\mathrm{Ca}^{2+}$ influx were calculated after background subtraction. Measurements of background were measured using a rectangular $30 \times 30$-pixel ROI. Using the equation and the optimized fit parameters, we converted any SypGCaMP signal to a linearized MagGreen (Invitrogen) equivalent proportional to the actual $\mathrm{Ca}^{2+}$. These linearized values were then used to estimate the effect of $\mathrm{Na}_{\mathrm{v}} \beta 2$ expression on single $\mathrm{AP} \mathrm{Ca}^{2+}$ responses (Ariel et al., 2012; Hoppa et al., 2012a). For measuring TTX susceptibility of synaptic boutons, we calculated $\Delta F / F$ of each bouton and determined its susceptibility if the $\Delta F / F$ after TTX treatment was $<10 \%$ of the initial value. To measure AP propagation at branch points, we counted electrically stimulated responsive boutons compared with nonresponsive boutons. First, we marked all synaptic boutons that showed increased $\mathrm{Ca}^{2+}$ influx level by perfusion of high $\mathrm{K}^{+}$solution. Next, we counted synaptic boutons, which were responsive to electrical stimulation. For counting synaptic bouton densities, we drew a box surrounding each branch and determined the "responsive boutons" that had increased fluorescence values compared with the backgrounds.

For quantifying the QuasAr signal, stimulation with 300 nM TTX was used to isolate the field stimulation from AP signal and was subtracted from our AP recordings at the soma and bouton. Generally, stimulation was made using $6 \mathrm{Vcm}^{-2}$ to minimize the stimulus signal. $\Delta F / F$ values of the AP were calculated after background subtraction (generally a $4 \times$ 10-pixel ROI). Finally, AP waveforms were corrected for the temporal resolution of QuasAr by deconvolution using an FFT-based algorithm in Origin Pro 8 with a normalized $500 \mu$ s exponential response function. Automated peak and full-width at half maximum (FWHM) analyses were performed using Origin Pro 8's peak-fitting algorithm.

For measuring axon diameter from the images taken by Airyscan, we used Fiji for image processing and analysis on raw data. A maximumintensity projection was applied to the images. To measure axon diameters around the branch points, a reference image was produced by thresholding and binarizing the raw image (Fiji). To define the regions, a $4 \mu \mathrm{m}$ line was drawn from the branch point to each axon branch and the area was measured automatically along the axon and occasionally boutons by analyze particle method in Fiji (see Fig. 4D). Data analysis for axon or bouton diameter was performed blinded to the conditions of the experiments. The average of axon diameter of each branch was calculated by division of the area by a $4 \mu \mathrm{m}$ line length. To acquire axon and bouton profiles, analysis was done by threshold images and axon shaft and boutons were selected along the regions. The line for measuring axon and bouton diameters was drawn perpendicularly along axon shafts.

\section{Results}

\section{Heterogeneous AP waveforms between axonal branches}

Recent measurements of APs in excitatory hippocampal neurons found a lower amplitude at presynaptic terminals compared with the soma (Hoppa et al., 2014), which likely indicates a lower density of $\mathrm{Na}_{\mathrm{v}} \mathrm{s}$ in the axon and/or presynaptic terminals of hippocampal neurons compared with $\mathrm{K}_{\mathrm{v}} \mathrm{s}$. We were therefore curious to determine whether this type of ion channel composition would lead to a loss of uniformity in the waveform of propagating APs. The fine structure of axons and presynaptic terminals emanating from hippocampal neurons is too small to use whole-cell patch clamp consistently to measure local ion currents or membrane potential directly across an arborization. Therefore, we chose to measure axonal AP propagation directly using a noninvasive genetically encoded $V_{\mathrm{m}}$ indicator, QuasAr (Hochbaum et al., 2014). QuasAr is an improved variant of the voltage sensor archaerhodopsin with extremely fast kinetics $(\sim 100 \mu \mathrm{s})$ and displays large linear responses to changes in membrane potential. Comparing it with electrophysiological recordings at the soma show that it can track membrane potential accurately and distort or filter measurements of AP shape minimally (Fig. 1A). QuasAr's improved brightness and excellent membrane trafficking (Fig. $1 B$ ) allow quantitative measurements of subcellular APs with a large signal-to-noise ratio that require less trial averaging to resolve the axonal AP waveform at high-time resolution ( $2 \mathrm{kHz}$; Fig. 1C). On average, axonal AP measurements displayed robust responses in fluorescence to field stimulation for single trials (signal-to-noise ratio of $4.6 \pm 0.4$ ), allowing detailed measurements of averaged AP waveforms (signal-to-noise ratio of $40.1 \pm 5.6$ for 100 trials). We examined the normal level of biophysical fidelity for the shape of an AP within a given branch (intrabranch) and between branches (interbranch) of normal hippocampal neurons (Fig. 1D). Therefore, we measured QuasAr waveforms within discrete sections of axons to compare AP waveform shape (Fig. 1E,F). Overall AP amplitude within a $10 \mu \mathrm{m}$ section of axon displayed a coefficient of variation $(\mathrm{CV})$ in 
A

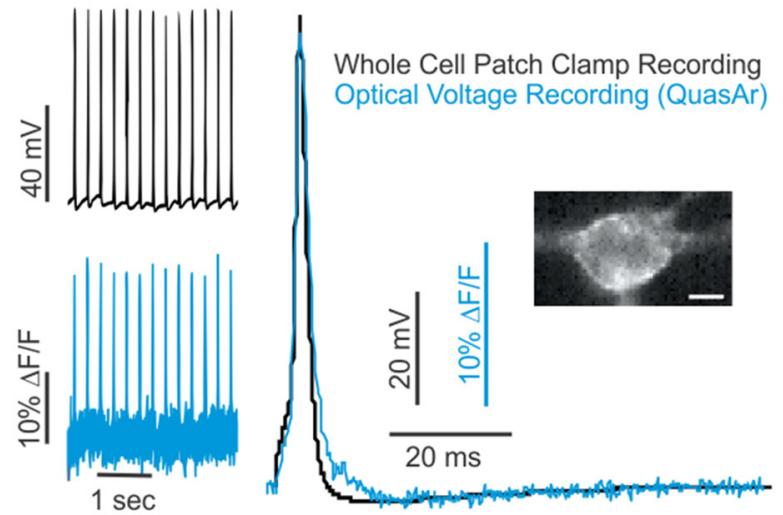

C

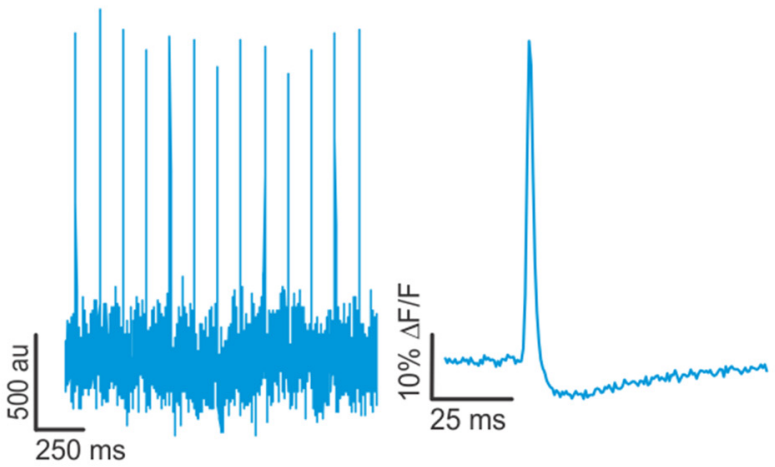

\section{E}

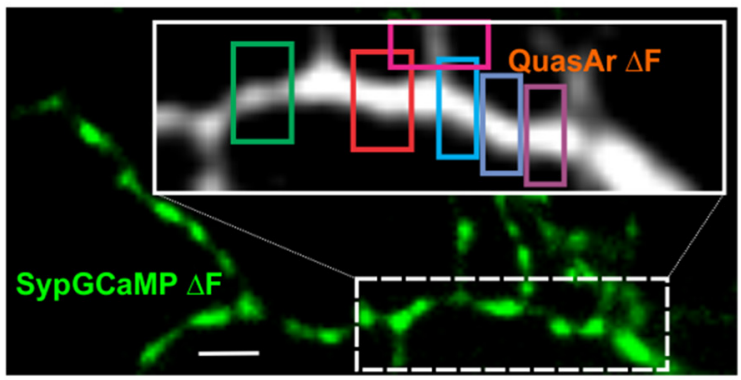

F

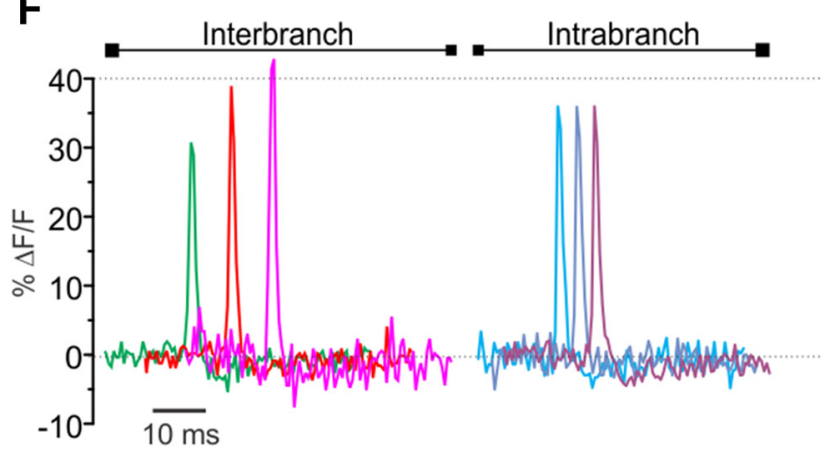

B

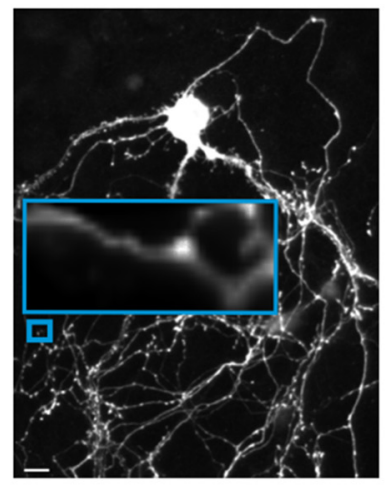

D

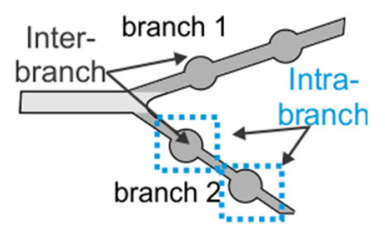

G

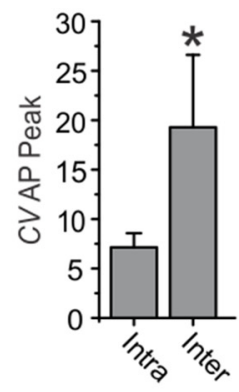

H

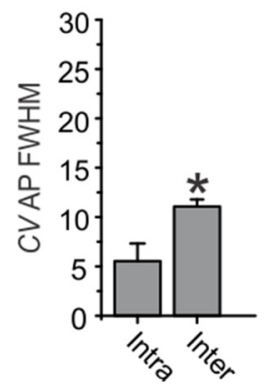

Figure 1. Heterogeneity of AP waveform across branches of the axonal arborization. A, Left, Simultaneous electrical (black) and optical (blue) recording of APs in a rat hippocampal neuron expressing QuasAr stimulated with $100 \mathrm{pA}$ current injections for $10 \mathrm{~ms}$ at $8 \mathrm{~Hz}$. Optical acquisition frame rate $2 \mathrm{kHz}$. Right, Average response from 40 trials peak aligned to electrophysiological APs. Inset shows basal QuasAr fluorescence. Scale bar, $5 \mu \mathrm{m}$. $\boldsymbol{B}$, Montage of several fields (mOrange fluorescence) from a dissociated hippocampal neuron expressing QuasAr-m0range. Inset image shows the axon branches expressing QuasAr's inherent fluorescence in far red. Scale bar, $20 \mu \mathrm{m}$. C, Left, QuasAr fluorescence intensity of the branches shown in $\boldsymbol{B}$ stimulated with single stimuli recorded at $2 \mathrm{kHz}$. Right, Average (100 trial) AP recorded from the branches shown in $\boldsymbol{B}(n=9)$. $\boldsymbol{D}$, Schematic model of axon branches describing intrabranch and interbranch boutons. $\boldsymbol{E}$, $\Delta$ Fimage of SypGCaMP (green) with inset showing $\triangle F$ DarkQuasAr fluorescence in white from stimulation with $1 \mathrm{AP}$. Scale bar, $5 \mu \mathrm{m}$. $\boldsymbol{F}$, AP waveforms from associated axon shown in $\boldsymbol{E}$ with colors of ROls matched with waveforms. $\boldsymbol{G}$, Coefficient of variation of AP peak between intrabranch and interbranch for three recorded regions of the axonal arborization $(n=8)$. $\boldsymbol{H}, \mathrm{CV}$ of AP FWHM between intrabranch and interbranch for the same cells in G. Error bars indicate mean \pm SEM. ${ }^{*} p=0.041$, Student's $t$ test. 
amplitude of $7.1 \pm 1.4$ for intrabranch, whereas the interbranch CV was $19.3 \pm 7.3$ (Fig. $1 G$ ). A difference was also observed for the FWHM between branches with a CV of $5.6 \pm 1.7$ intrabranch and $11.1 \pm 0.7$ interbranch (Fig. $1 H)$. Different membrane insertion of the QuasAr indicator cannot be ruled out as a source of variability in AP amplitude between branches. However, variable membrane insertion of our indicator would not explain the variability in interbranch FWHMs. No branches failed to respond to stimulation when measuring from three different axonal branches of an arborization and no noticeable bleaching was observed in our measurements. These results indicate significant heterogeneity of the AP waveform between branches of the unmyelinated axon. The changes in interbranch amplitude could be related to heterogeneous $\mathrm{Na}_{\mathrm{v}}$ activity across the unmyelinated axon branches.

\section{Heterogeneous $\mathrm{Na}_{\mathrm{v}}$ activity between axonal branches}

QuasAr requires high temporal sampling rates that necessitate small sampling windows $(\sim 12 \times 32 \mu \mathrm{m})$, so we required a slower indicator to measure large sections of the axonal arborization at lower sampling rates. Therefore, we turned to measurements of $\mathrm{Ca}^{2+}$ as a proxy for AP arrival across the axonal arborization (Cox et al., 2000) using the $\mathrm{Ca}^{2+}$ indicator GCaMP6F (>20 ms response kinetics) (Chen et al., 2013) fused to synaptophysin (SypGCaMP) for synapse specificity (Li et al., 2011) to give a robust indication of AP arrival at synaptic terminals (Fig. $2 A$ ). To determine relative $\mathrm{Na}_{\mathrm{v}}$ activity across the axonal arborization, we challenged control neurons by perfusing low concentrations (1-30 nM) of TTX and stimulating neurons expressing SypGCaMP with a brief train of APs. TTX is a broad inhibitor of $\mathrm{Na}_{\mathrm{v}}$ channels. Surprisingly, we did not detect uniform TTX sensitivity across a single axonal arborization. Instead, we observed a significant heterogeneity in TTX sensitivity for a single neuron, in which individual branches of the axon stopped responding to stimulation at different concentrations of TTX and "failed" to propagate (Fig. 2B, red and yellow arrows). We defined branch failures in these measurements as a decrease in $\Delta F / F$ of SypGCaMP after TTX treatment that was $<10 \%$ of pre-TTX fluorescence (3-fold above the SD of baseline fluorescence). Individual branches started to demonstrate AP propagation failure even with very low $(\sim 1 \mathrm{nM})$ levels of TTX, consistent with comparatively high TTX sensitivity in excitatory axons, as described previously (Prakriya and Mennerick, 2000). Nevertheless, some branches still retained AP-evoked $\mathrm{Ca}^{2+}$ responses at $30 \mathrm{~nm}$ TTX despite elaborating from a single cell (Fig. $2 C)$. This unexpected heterogeneous response to TTX was not due to impaired health of the hippocampal neuron over the course of the experiment because all $\mathrm{Ca}^{2+}$ responses returned to initial levels after TTX washout (Fig. $2 C, D$ ). Although unlikely due to our small perfusion volumes $(<150 \mu \mathrm{l})$ used in live-cell imaging, we tested whether these heterogenous responses to TTX could be due to local variability in TTX concentration resulting from perfusion. Therefore, we used a static bath application of TTX and repeated the measurements across multiple trials. The failed response of certain branches to AP stimulation was consistent across trials, with the same branches failing to respond to subsequent rounds of stimulation for $>30 \mathrm{~min}$ (Fig. 2E). The large variability in TTX susceptibility across branches of a single axonal arborization suggests a significant local heterogeneity in $\mathrm{Na}_{\mathrm{v}}$ activity or a molecular repertoire of ion channels and associated subunits between branches of the unmyelinated axon.

\section{Branch points demarcate variability in AP propagation}

Interestingly, when mature (DIV 14-23) neurons were challenged with TTX, the loss of AP-evoked $\mathrm{Ca}^{2+}$ was not selective for individual boutons, but was for contiguous boutons along select axonal branches. To confirm the location of failures more clearly, we also measured SypGCaMP signals in less complicated axonal arborizations from DIV 12-13 neurons, in which we could often trace the origin of failures to what appeared to be bifurcations (Fig. 3A). Recent studies have found local changes of the AP in other small-diameter axons, indicating a more active contribution of local voltage-gated ion channels to electrical signaling (Kawaguchi and Sakaba, 2015; Rowan et al., 2016). Therefore, we measured synaptic $\mathrm{Ca}^{2+}$ responses at a branch level in relation to TTX propagation failures (Fig. 3B). To accomplish this task, we measured SypGCaMP responses in branches of an axonal arbor by stimulating with 10 AP trains before and after TTX application at various concentrations until we could identify $>30 \%$ of synapses failing (Fig. $3 C$ ). To determine the physiological significance of branch responses to TTX in relation to synaptic $\mathrm{Ca}^{2+}$ influx, we measured synaptic $\mathrm{Ca}^{2+}$ level for $1 \mathrm{AP}$ stimulation in branches of axons that responded to AP stimulation in the presence of TTX (TTX-Success) and those that did not (TTX-Failure) (Fig. 3D). We found that TTX-Success branches of the axon had a significantly higher $(19 \%)$ increases in $\mathrm{Ca}^{2+}$ influx $(0.82 \pm 0.05 \Delta F / F)$ compared with TTX-Failure branches $(0.68 \pm 0.05 \Delta F / F)$ (Fig. $3 E$ ). These results indicate a potentially significant role of branches of an arborization to tune presynaptic output that is molecular or geometrical in nature.

\section{Axon geometry does not alter AP propagation fidelity}

As APs actively propagate through unmyelinated sections of the axon, they encounter several geometric irregularities such as en passant boutons and branch points. These changes in diameter and membrane surface along the axon may alter the AP waveform (Lüscher and Shiner, 1990). We assessed this possibility experimentally by measuring axon morphology optically beyond the diffraction limit at $125 \mathrm{~nm}$ resolution using an Airyscan (Zeiss) detector to measure axon geometry taking advantage of QuasAr's excellent membrane trafficking with a representative image shown in Figure $4 A$. We combined this sensitive spatial resolution with SypGCaMP responses with or without TTX to induce branch point failures and measured differences in morphology related to AP propagation success. Measuring in both indicators separately was possible due to the orthogonal emission spectra of the mOrange2-labeled QuasAr and GFP-based GCaMP (Fig. 4B). We assessed SypGCaMP responses from a train of 20 APs delivered at $20 \mathrm{~Hz}$ before and after TTX application (Fig. 4B). Failures were identified by an average drop of $>90 \%$ in $\mathrm{Ca}^{2+}$ influx before TTX application across all adjacent boutons of an axonal branch. An example of SypGCaMP measurements is shown in Figure $4 C$ of the intersection of three axon collaterals at one branch point from the axon shown in Figure $4 B$. We then measured the average diameter (axon + boutons) of branches under TTX application that had a successful (TTXSuccess) or failed (TTX-Failure) AP-induced $\mathrm{Ca}^{2+}$ response. Figure $4 D$ shows the diameter measurements corresponding to branches, "a-c" from Figure $4 B$. Overall, we did not find any significant difference between the average axonal diameter of branches that failed or were successful (TTX-Success; $602 \pm 49$ $\mathrm{nm}$, TTX-Failure; $656 \pm 65 \mathrm{~nm}, p>0.1$; Fig. $4 E$ ). As a control, we also compared the axon diameters of branches that did not display any failure when challenged with low $(<9$ nM) TTX, which were also nearly identical to impaired branches in morphology $(631 \pm 49 \mathrm{~nm}, p>0.1$; Fig. $4 E)$. To verify how well our preparation of QuasAr-transfected cells represented hippocampal neurons with Airyscan resolution, we measured the axon and 
A

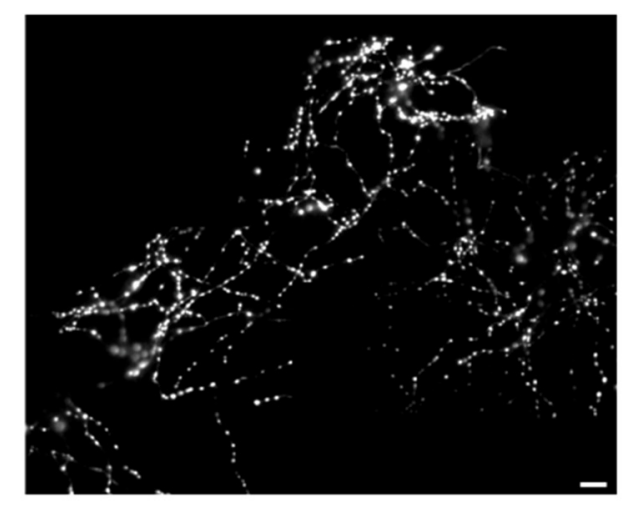

C

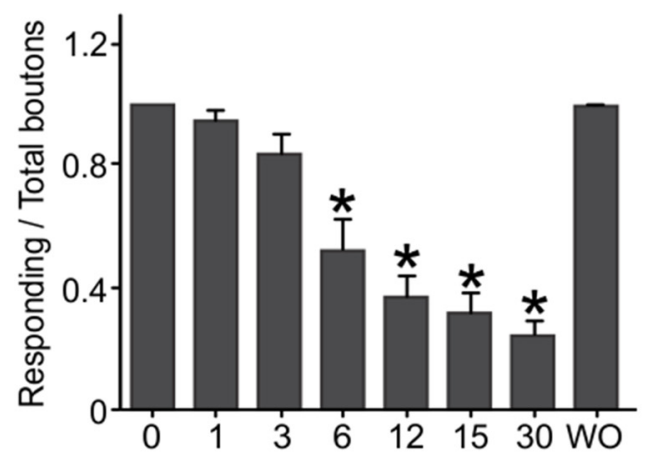

E
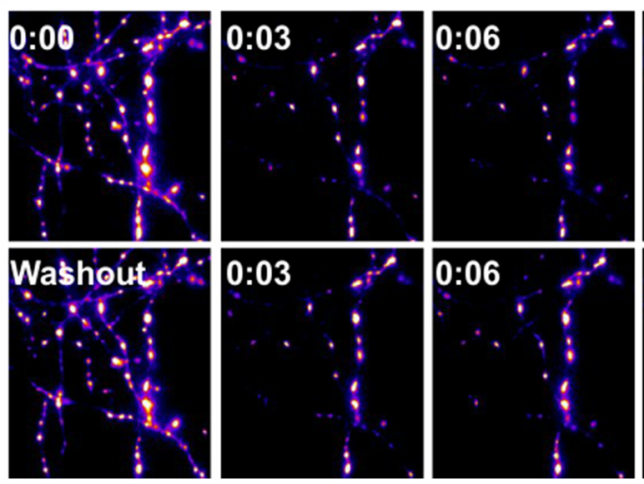

B

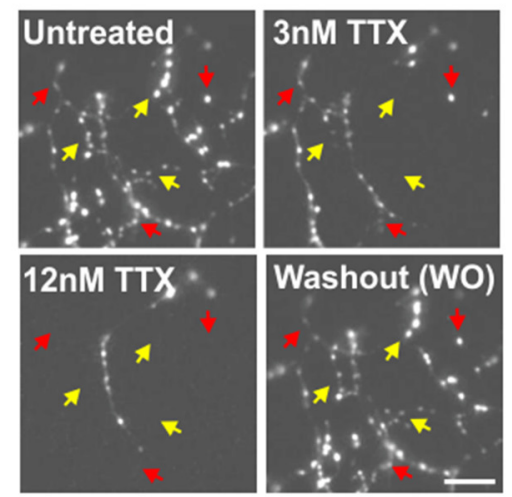

D

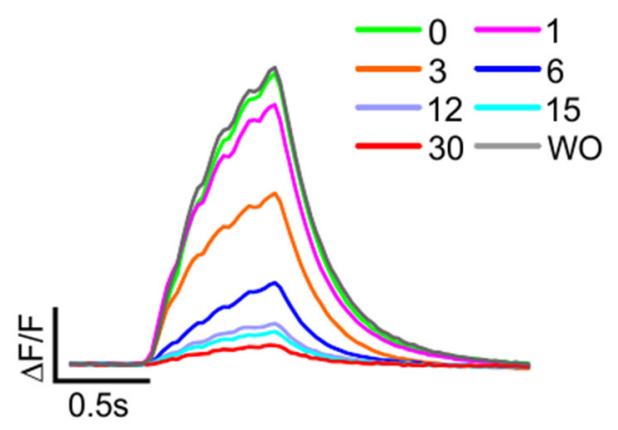

1 nM TTX
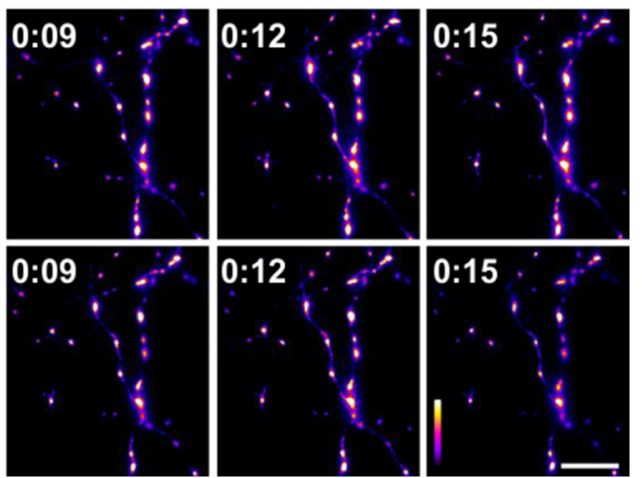

Figure 2. Heterogeneity of TTX sensitivity across branches of the axonal arborization. $A$, Montage of $\Delta F$ images obtained for trains of $20 \mathrm{AP}$ at $20 \mathrm{~Hz}$ stimulation from one axon in a dissociated hippocampal neuron expressing SypGCaMP. Scale bar, $20 \mu \mathrm{m}$. B, Representative $\Delta$ Fimage obtained for a 20 AP stimulus with different concentrations of TTX from a SypGCaMP transfected neuron's axonal field. Yellow arrows indicate branches which were sensitive to $3 \mathrm{~nm} \mathrm{TTX} \mathrm{treatment} \mathrm{and} \mathrm{red} \mathrm{arrows} \mathrm{indicate} \mathrm{branches} \mathrm{that} \mathrm{were} \mathrm{sensitive} \mathrm{to} 12 \mathrm{~nm}$ TTX treatment. Scale bar, $20 \mu \mathrm{m}$. C, Ratio of responsive boutons to $20 \mathrm{AP}$ stimulus with different concentrations of TTX and washout (W0) to that of $20 \mathrm{AP}$ stimulus without TTX $(n=9)$. Error bars indicate mean \pm SEM. ${ }^{*} p<0.05, \mathrm{ANOVA}$ with Tukey's post hoc comparisons. D, Average trace of measured SypGCaMP response to $20 \mathrm{AP}$ stimulus under control condition and with TTX and washout (W0). $E, \Delta F$ SypGCaMP images of an axonal field stimulated with a train of $10 \mathrm{AP}$ at $50 \mathrm{~Hz}$ stimulation at various time points before and in the presence of $1 \mathrm{~nm} \mathrm{TTX.} \mathrm{TTX} \mathrm{incubation} \mathrm{induced} \mathrm{selective} \mathrm{AP} \mathrm{propagation} \mathrm{failure} \mathrm{in} \mathrm{the} \mathrm{same} \mathrm{branches}$ across each trial (time points for TTX application in top right corner of image). Toxin was washed out and reapplied for the second row; note the repeated loss of selective branches of synapses from the axonal field. Scale bar, $20 \mu \mathrm{m}$.

boutons diameters across the arborization (Fig. $4 F$ ) with synaptic identity confirmed by SypGCaMP responses. We found that our cells had an average axon diameter of $(392.28 \pm 5.58 \mathrm{~nm}, 428$ axon segments, $n=22$ cells; Fig. $4 G$, top) and bouton diameter of ( $964.01 \pm 19.56 \mathrm{~nm}, 265$ boutons, $n=22$ cells; Fig. 4G, bottom), which are in excellent agreement with previous measurements of axons $(\sim 200 \mathrm{~nm})$ from neuropil of the hippocampus using electron microscopy (Mishchenko et al., 2010) taking diffraction of light into account. Although axon diameter was not related to the success/failures of AP propagation, we also assessed how bouton density alters propagation success because boutons often have much higher changes in geometric ratio than axon branch points. To assess this possibility, we measured synaptic bouton density along sections of the axon using SypGCaMP as a marker comparing collaterals of successful verses failed propagation when challenged with TTX. Again, we did not find any differences between branches based on the density of en passant synapses that were predictive of propagation failures $(n=8$ cells, $p=0.910$; data not shown). Together, these results suggest that geometry and impedance mismatches alone are not predictive of propagation fail- 
A
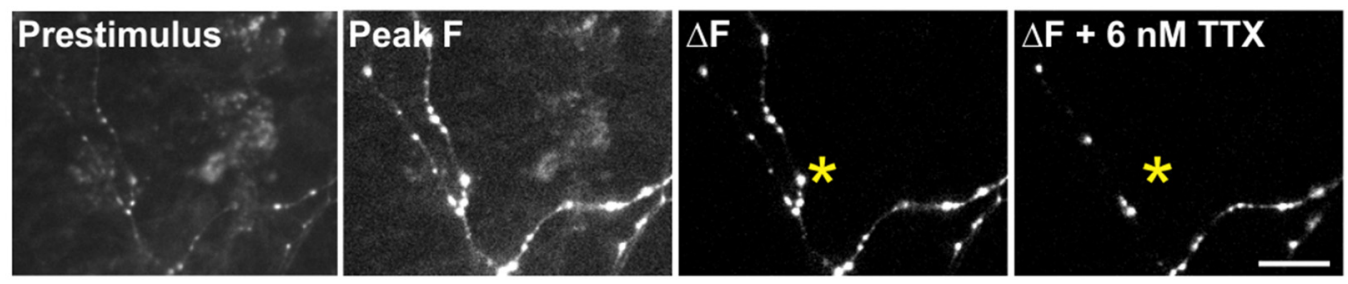

C

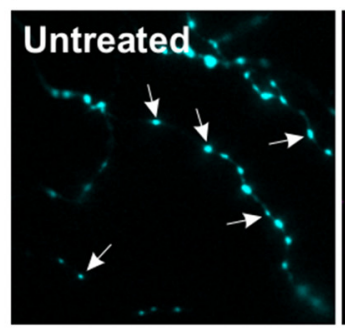

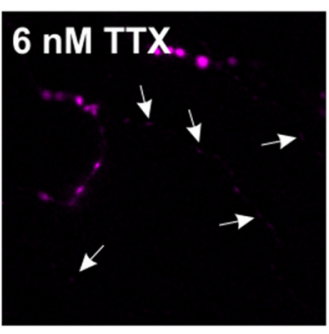

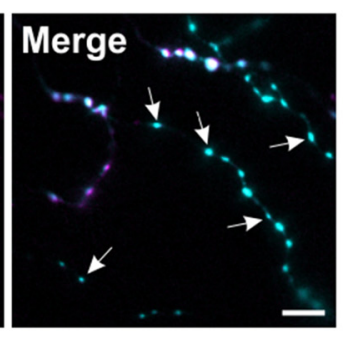

D

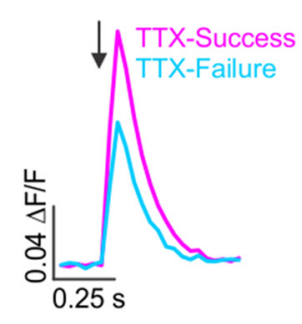

B

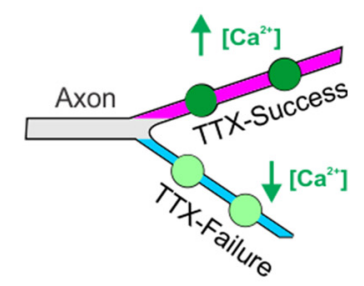

$\mathbf{E}$

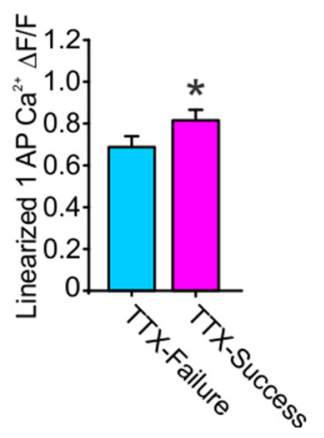

Figure 3. $\mathrm{Na}_{\mathrm{v}}$ activity levels influence synaptic $\mathrm{Ca}^{2+}$ influx at the level of branches within the axon. $A, \Delta F$ SypGCaMP $\pm 6 \mathrm{~nm}$ TTX stimulated with a train of $20 \mathrm{APs}$ at $20 \mathrm{~Hz}$. TTX induced AP propagation failure that occurred at a branch point of the axon $\left({ }^{*}\right)$.Scale bar, $20 \mu \mathrm{m}$. B, Schematic model of axonal $\mathrm{Na}_{v}$ sinfluencing the magnitude of presynaptic $\mathrm{Ca}^{2+}$ influx. Branches will respond successfully to AP stimulation when challenged with TTX (TTX-Success) or fail to respond (TTX-Failure). C, $\Delta F$ images obtained for the trains of $10 \mathrm{AP}$ at $50 \mathrm{~Hz}$ stimulation in untreated and $6 \mathrm{~nm}$ TTX conditions. Blue- and pink-colored boutons indicate successful and failed responses to $6 \mathrm{~nm} \mathrm{TTX,} \mathrm{respectively.} \mathrm{Scale} \mathrm{bar,} 20 \mu \mathrm{m}$. D, Presynaptic Ca ${ }^{2+}$ influx induced by a single AP stimulus (arrow) from post hoc identified TTX-Success and TTX-Failure branches. $\boldsymbol{E}$, Averaged linearized single AP $\Delta F / F$ increases in TTX resistant branches in untreated neurons $(n=15) .{ }^{*} p=0.0028$; paired $t$ test. Error bars indicate mean \pm SEM.

ures at branch points, suggesting that diversified and local molecular repertoires within the axon dominate this process.

\section{$\mathrm{Na}_{\mathrm{v}} \boldsymbol{\beta 2}$ modulates AP-evoked calcium entry at presynaptic terminals}

Given $\mathrm{Na}_{\mathrm{v}} \beta 2$ 's previously implicated role for controlling $\mathrm{Na}^{+}$ currents in myelinated axons, we decided that $\mathrm{Na}_{\mathrm{v}} \beta 2$ would be a good candidate with which to modulate axonal $\mathrm{Na}^{+}$in unmyelinated axons and $\mathrm{AP}$-evoked $\mathrm{Ca}^{2+}$ at synapses. We confirmed the presence of $\mathrm{Na}_{\mathrm{v}} \beta 2$ in our cultures, as well as the $\mathrm{Na}_{\mathrm{v}} \alpha 1.2$ and $\mathrm{Na}_{\mathrm{v}} \alpha 1.6$, the expression of which increased markedly during maturation (Fig. $5 A, D$ ). We made use of shRNA-targeted knockdown to deplete endogenous levels of $\mathrm{Na}_{\mathrm{v}} \beta 2$ cotransfected with SypGCaMP. Genetic knock-down resulted in an $\sim 70 \%$ depletion of endogenous levels of $\mathrm{Na}_{\mathrm{v}} \beta 2(p<0.05$; Fig. $5 B, E)$. To confirm specificity of knock-down by Western blot and to quantify knock-down efficiency, we used rat-derived INS-1 cells due to their ease of transfection, which showed $94 \%$ depletion of endogenous levels of $\mathrm{Na}_{\mathrm{v}} \beta 2$ when correcting for transfection efficiency $(p<0.05$; Fig. $5 C, F)$. Next, to determine the role of $\mathrm{Na}_{\mathrm{v}} \beta 2 \mathrm{~s}$ in modulating axonal $\mathrm{Na}^{+}$and AP-evoked $\mathrm{Ca}^{2+}$ at synapses, we made use of shRNA-targeted knock-down in conjunction with measurements of $\mathrm{Ca}^{2+}$ influx using SypGCaMP. We compared $\mathrm{Ca}^{2+}$ influx in the two conditions by stimulating with a train of $20 \mathrm{APs}$ at $20 \mathrm{~Hz}$ while imaging at $100 \mathrm{~Hz}$ (Fig. 6A). This rapid optical sampling allowed us to extract a measurement of $\mathrm{Ca}^{2+}$ influx in response to individual APs during the train of stimulations (Fig. 6B). We converted this nonlinear response of the $\mathrm{Ca}^{2+}$ indicator based on the reported Hill coefficient for GCaMP6F fluorescent responses to various $\mathrm{Ca}^{2+}$ concentrations (Chen et al., 2013). Peak $\mathrm{Ca}^{2+}$ influx during the train was not reduced (Fig. 6C). However, when stimulated with a single AP, the re- sponse from $\mathrm{Na}_{\mathrm{v}} \beta 2$ shRNA-transfected neurons was reduced by half $(47.5 \pm 4.0 \% ; p<0.05)$ compared with control neurons (Fig. $6 D$ ). Single AP stimulations were more strongly impaired by $\mathrm{Na}_{\mathrm{v}} \beta 2$ deficiency compared with trains. We attribute this observation to the slow off-rates of the GCaMP reporter, which can complicate $\mathrm{Ca}^{2+}$ influx measurements during AP trains. We were curious whether this reduction in $\mathrm{AP}$-evoked $\mathrm{Ca}^{2+}$ influx was for a select population of measured synapses within a single axonal arborization or if they were universally reduced. Therefore, we also measured single $\mathrm{AP} \mathrm{Ca}^{2+}$ responses for individual synapses and found a shift in peak responses more consistent with an overall reduction with $\mathrm{Na}_{\mathrm{v}} \beta 2$ shRNA (Fig. $6 E$ ). These results suggest that $\mathrm{Na}_{\mathrm{v}} \beta 2$ plays an important role in controlling axonal $\mathrm{Na}_{\mathrm{v}}$ activity levels and its loss impairs AP-evoked $\mathrm{Ca}^{2+}$ influx. We speculated that $\mathrm{Na}_{\mathrm{v}} \beta 2$ shRNA-transfected cells may have a lower density of functional $\mathrm{Na}_{\mathrm{v}} \mathrm{s}$ within the axon either due to altered voltage sensitivity or membrane insertion. Therefore, axonal TTX sensitivity should be increased in $\mathrm{Na}_{v} \beta 2$ shRNAtransfected neurons. We compared $\mathrm{Ca}^{2+}$ influx as a proxy for AP propagation across the arborization of control, $\mathrm{Na}_{\mathrm{v}} \beta 2$ shRNAtransfected neurons, and neurons overexpressing a human variant of $\mathrm{Na}_{\mathrm{v}} \beta 2\left(\mathrm{hNa} \mathrm{v}_{\mathrm{v}} \beta 2 \mathrm{OE}\right)$, respectively (Fig. $\left.6 F\right)$. We observed a significant shift in TTX sensitivity for $\mathrm{Na}_{\mathrm{v}} \beta 2$ shRNA-transfected neurons with much higher failure rates to lower concentrations of TTX between 1 and 12 nM TTX application ( $p<0.05$; Fig. $6 G$ ). No observable shift was seen in TTX resistance for $\mathrm{hNa}_{\mathrm{v}} \beta 2 \mathrm{OE}$ neurons, indicating potential endogenous saturation levels of the subunit. The combined results of impaired AP-evoked $\mathrm{Ca}^{2+}$ influx and increased TTX sensitivity suggest that $\mathrm{Na}_{\mathrm{v}} \beta 2$ deficiency impairs $\mathrm{Na}_{\mathrm{v}}$ activity directly within the unmyelinated axon or there is a significant shift in the balance of $\mathrm{Na}_{\mathrm{v}}$ and $\mathrm{K}_{\mathrm{v}}$ channels. 
A

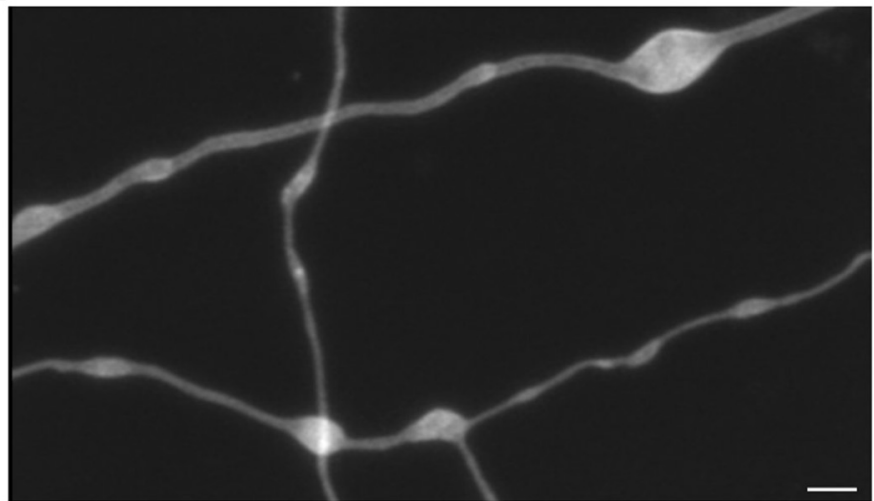

C

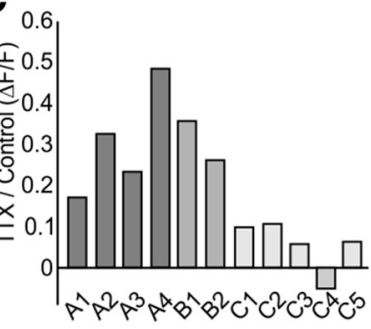

D
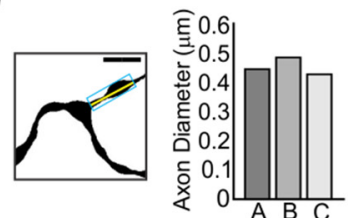

E

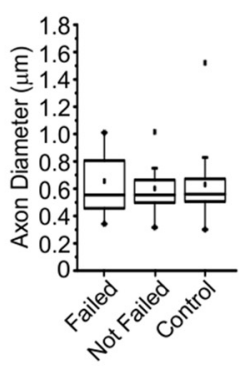

B
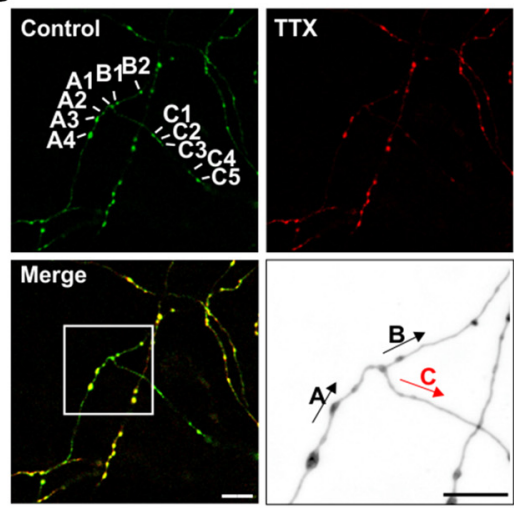

G
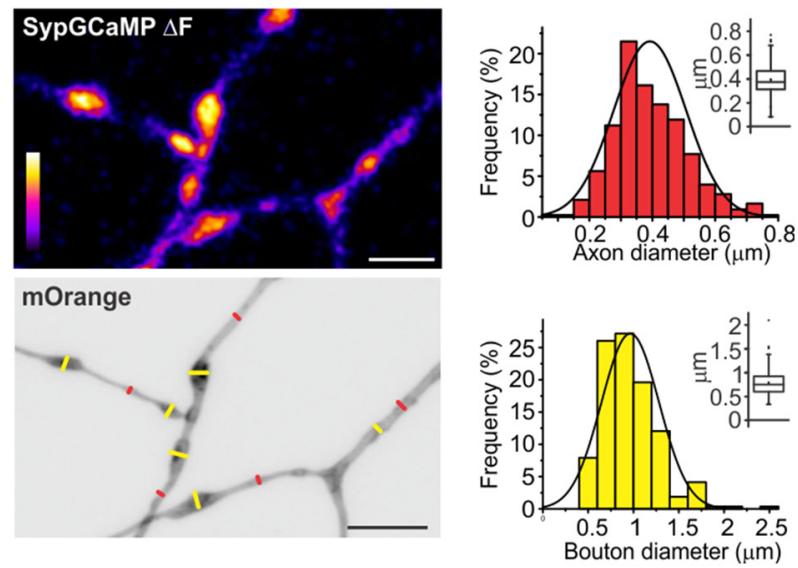

Figure 4. Axon branch point morphology is independent of AP propagation failure. $\boldsymbol{A}$, Representative Airyscan image of axons from a hippocampal neuron. Scale bar, $2 \mu \mathrm{m} . \boldsymbol{B}$, Representative $\Delta$ F image obtained from SypGCaMP for a 20 AP stimulus with control (green) and $6 \mathrm{~nm} \mathrm{TTX} \mathrm{(red)} \mathrm{with} \mathrm{merged} \mathrm{images} \mathrm{below.} \mathrm{Inset} \mathrm{image} \mathrm{is} \mathrm{an} \mathrm{expanded} \mathrm{and} \mathrm{inverted} \mathrm{Airyscan} \mathrm{image} \mathrm{of} \mathrm{m0range}$ signal from QuasAr to show axon morphology shown in black and white for clarity. Scale bar, $10 \mu \mathrm{m}$. C, Ratio of $\Delta F / F$ from $20 \mathrm{AP}$ stimulus (TTX/Control) for the axon branches labeled in ( $\boldsymbol{B}$; top left). $D$, Left, Method to measure axon diameter strategy. Area was measured from thresholded region in the rectangle (blue) in a $4 \mu \mathrm{m}$ length section of the axon (yellow line) to obtain an average diameter. Scale bar, $2 \mu \mathrm{m}$. Right, Average of axon diameter around axon branch point from B.E. Average axon diameter from neurons showing AP propagation failure and success at branch points ( $n=9$ cells) and control neurons ( $n=10$ cells). $\boldsymbol{F}$, Top, Representative SypGCaMP $\Delta F$ image from stimulation with a 20AP train of APs $(20 \mathrm{~Hz})$. Bottom, Representative Airyscan image of axon (QuasAr mOrange signal). Red line indicates diameter of axon shaft and yellow line indicates bouton diameter. Scale bar, $5 \mu \mathrm{m}$. G, Distribution of axon diameters (top) and bouton diameters (bottom) collected from 22 cells.

\section{$\mathrm{Na}_{\mathrm{v}} \boldsymbol{\beta} 2$ modulates the axonal AP waveform}

To assess the relationship between $\mathrm{Na}_{\mathrm{v}} \beta 2$ and the sculpting of the AP waveform within the unmyelinated axon, we made subcellular measurements using QuasAr. We first measured AP initiation by recording from the soma under control and $\mathrm{Na}_{\mathrm{v}} \beta 2$ shRNA conditions (Fig. 7A). We found that the somatic APs generated immediately after initiation of the AP at the axon initial segment were similar in amplitude $(p=0.54)$ between control (30.2 \pm $3.7 \%$ ) and $\mathrm{Na}_{\mathrm{v}} \beta 2$ shRNA-transfected neurons ( $33.5 \pm 2.2 \%$; Fig. $7 B$ ). This was also true of the overall AP shape with hyperpolarization and decay; we compared their FWHM between conditions, which were also similar $(p=0.93)$ between control (1.26 \pm $0.05 \mathrm{~ms})$ and $\mathrm{Na}_{\mathrm{v}} \beta 2$ shRNA-transfected neurons $(1.27 \pm 0.12$ ms; Fig. $7 C$ ). These results indicate that $\mathrm{Na}_{\mathrm{v}} \beta 2$ does not play an essential role in AP initiation despite some enrichment within the axon initial segment (Fig. 7A), which matches previous data ascribing a more defined functional role for $\mathrm{Na}_{\mathrm{v}} \beta 1$ at the axon initial segment and soma of excitatory neurons (Wimmer et al., 2010). However, recordings of the axonal AP (Fig. 7D) showed that $\mathrm{Na}_{\mathrm{v}} \beta 2$ shRNA-transfected cells displayed a significantly $(p=0.037)$ reduced AP amplitude $(31.9 \pm 1.8 \% \Delta F / F)$ compared with control cells $(37.4 \pm 2.6 \% \Delta F / F$; Fig. $7 E)$. There was not a significant difference between the FWHM of these record- ings $(p=0.26)$ in control $(1.4 \pm 0.1 \mathrm{~ms})$ and $\mathrm{Na}_{\mathrm{v}} \beta 2$ shRNAtransfected neurons $(1.6 \pm 0.1 \mathrm{~ms}$; Fig. $7 F)$. Strikingly, $\mathrm{Na}_{\mathrm{v}} \beta 2$ shRNA-transfected neurons displayed a loss of successful AP potential propagation fidelity in control conditions using optical measurements of membrane potential across the arborization, with a representative cell and recording shown in Figure 7G. We were able to measure the axonal AP in $\mathrm{Na}_{\mathrm{v}} \beta 2$ shRNA-transfected neurons successfully in at least three spatially distinct branches (10 $\mu \mathrm{m}$ section) of the axonal arborization for each cell. All control cells responded with a defined AP spike, whereas $<15 \%$ of $\mathrm{Na}_{\mathrm{v}} \beta 2$ shRNA cells had AP responses across all measured branches of the axon (Fig. $7 H$ ). Importantly, all axonal recordings were made from cells in both conditions in which successful AP generation could be observed at the soma indicating robust electrical excitability. To ensure that our field-stimulus protocol initiates AP generation at the axon initial segment, we used a very low input stimulus $\left(6 \mathrm{Vcm}^{-2}\right.$; see Materials and Methods). When we made distinct subcellular measurements of AP arrival at the soma compared with the distal axon, we found a reliable delay of AP peaks of $\sim 1.2 \pm 0.4 \mathrm{~ms}$ depending on the measurement location within the arborization (using $2 \mathrm{kHz}$ sampling; Fig. 7I). Considering that these neurons have an estimated conduction velocity of $\sim 0.25 \mathrm{~ms}^{-1}$ (Andersen et al., 2000), this measurement 
A

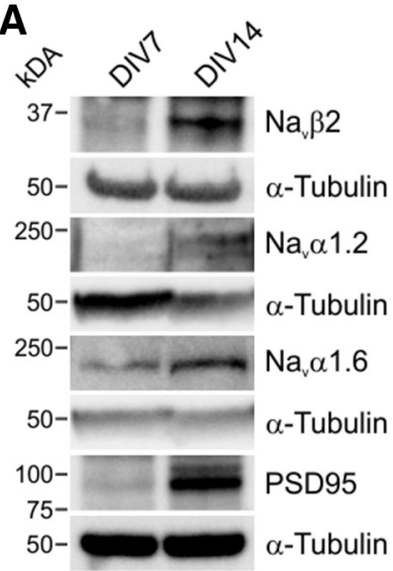

D

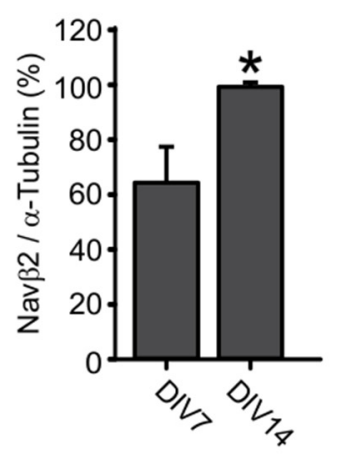

B
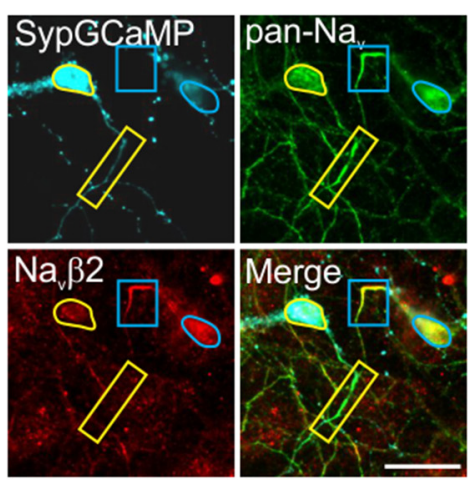

C

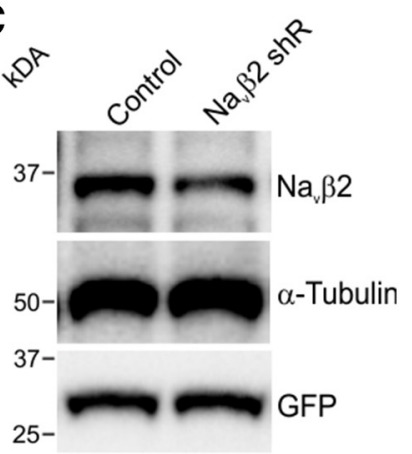

E

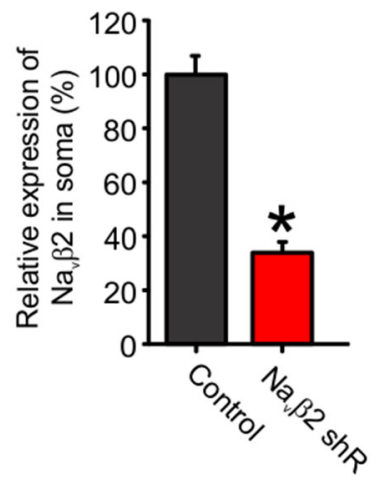

$\mathbf{F}$

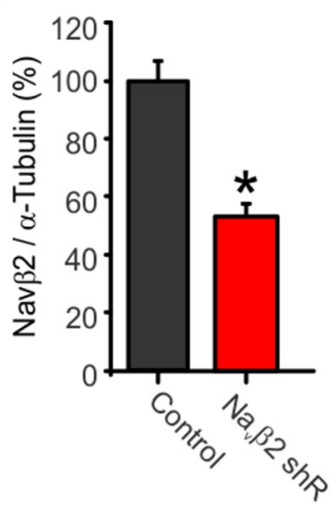

Figure 5. Sodium channel subunit expression during axon maturation and knock-down of $\mathrm{Na}_{\mathrm{v}} \beta 2$. $\boldsymbol{A}$, Representative Western blot of $\mathrm{Na}_{\mathrm{v}} \beta 2$, $\mathrm{Na}_{\mathrm{v}} \alpha 1.2$, $\mathrm{Na}_{\mathrm{v}} \alpha 1$.6, and PSD-95 with matching bands of $\alpha$-tubulin (paired to sample shown above) to control for total protein loaded from cultured rat hippocampal neurons from DIV 7 and 14 to represent nascent axons and mature axons. $\boldsymbol{B}$, Immunofluorescence staining for SypGCaMP (anti-GFP antibody), $\mathrm{Na}_{v} \mathrm{~s}$ (pan- $\mathrm{Na}_{v}$ antibody), and $\mathrm{Na}_{v} \beta 2$ in primary cultured hippocampal neurons cotransfected with SypGCaMP and Na $\mathrm{a}_{v} \beta 2$ shRNA. Boxes indicate axon initial segment, yellow lines indicate transfected neurons and blue lines indicate nontransfected neurons. Scale bar, $20 \mu \mathrm{m}$. C, Representative Western blot of Na $\beta 2, \alpha$-tubulin, and GFP from rat INS- 1 cells to confirm the specificity of the shRNA of $\mathrm{Na}_{\mathrm{v}} \beta 2$. GFP was cotransfected for visualization of transfection efficiency (50.75\%; $n=400$ cells). $\boldsymbol{D}, \mathrm{Quantification} \mathrm{of} \mathrm{Na}, \beta 2$ expression in cultured rat hippocampal neurons. $\mathrm{Na}_{\mathrm{v}} \beta 2$ expression increases during axon maturation in primary cultured hippocampal neurons from DIV 7 to DIV $14 . n=5$ individual cultures from a combination of several pups of mixed genders; ${ }^{*} p=0.018$ with DIV 7 group, Student's $t$ test. $\boldsymbol{E}$, Quantification of relative expression of Na $\beta 2$ in soma of $\mathrm{Na}_{\mathrm{v}} \beta 2$ shRNA-transfected neurons compared with control neurons ( $n=25$ for control, $n=8$ for $\mathrm{Na}_{\mathrm{v}} \beta 2$ shRNA-transfected neurons). ${ }^{*} p=0.0095$, Student's $t$ test. $\boldsymbol{F}$, Quantification of Na $\beta 2$ expression in rat INS-1 cells. Quantification of bands displays a $53 \pm 4 \%$ expression for shRNA exposed cells. Based on a $50.75 \%$ transfection efficiency, this predicts a $94 \%$ knock-down efficiency $(n=3$ individual cultures and transfections). ${ }^{*} p=0.0014$, Student's $t$ test.

seems consistent with estimations of delay, although a calculation of exact distance is missing because the circuitous route and prolific complexity of axon networks in cultured neurons renders exact estimations of distance and branching order impossible. If AP initiation were induced locally within the axon, then recorded delay would not be measured. As a whole, these results describe a particularly critical role for $\mathrm{Na}_{\mathrm{v}} \beta 2$ in the distal axon to enable successful propagation of the AP waveform.

\section{$\mathrm{Na}_{\mathrm{v}} \boldsymbol{\beta} 2$ maintains AP propagation fidelity}

To examine the propagation success of AP invasion across the arborization in greater detail for $\mathrm{Na}_{\mathrm{v}} \beta 2$-deficient neurons, we sought a robust method to reveal the nonresponding branches that our QuasAr measurements identified across the axonal arborization. We elicited $\mathrm{Ca}^{2+}$ influx using two stimulation protocols: the first was AP-evoked from field stimulation and the other was caused by a uniform membrane depolarization stimulated by a brief $(5 \mathrm{~s})$ perfusion of high $\mathrm{K}^{+}(90 \mathrm{~mm})$ to open presynaptic $\mathrm{Ca}_{\mathrm{v}}$ (Fig. 8A). We found that all genetic conditions responded nearly identically to high $\mathrm{K}^{+}$stimulation with a nonsaturating $\sim 650 \% \Delta F / F$ in all boutons ruling out a defect in synaptic $\mathrm{Ca}_{\mathrm{v}}$ trafficking (Fig. 8B). Comparing these two stimulation condi- tions allowed us to determine any responsive boutons that failed to display evoked-Ca ${ }^{2+}$ influx during electrical stimulation. This assay allowed us to identify AP propagation failures robustly. It has been reported previously that excitatory pyramidal neurons have nearly perfect reliability to transmit single APs and trains of stimulation using injected $\mathrm{Ca}^{2+}$ dyes to measure AP arrival (Cox et al., 2000). We confirmed these previous findings are also true in our cultured neurons, in which we observed that AP propagation was nearly perfect in control cells when comparing electrical and high $\mathrm{K}^{+}$stimulation $(99.6 \pm 0.3 \%)$. Interestingly, we found that $\mathrm{Na}_{\mathrm{v}} \beta 2$ shRNA-transfected neurons showed prolific branch failures within the arborization for AP propagation, with only $62.0 \pm 3.5 \%$ of boutons responding to electrical stimulation (Fig. $8 C$ ). We explored how unique this phenotype was for the $\mathrm{Na}_{\mathrm{v}} \beta 2$ by also subjecting cells to $\mathrm{Na}_{\mathrm{v}} \beta 4$ depletion using a commercially validated shRNA directed against this related subunit because it was found recently to play a role in the axons of striatal neurons (Miyazaki et al., 2014). $\mathrm{Na}_{\mathrm{v}} \beta 4$ shRNA-transfected neurons did not elicit any branch point failures, suggesting that AP propagation at branch points is controlled selectively by $\mathrm{Na}_{v} \beta 2 \mathrm{~s}$ in these excitatory hippocampal neurons (Fig. $8 C$ ). Knock-down of $\mathrm{Na}_{\mathrm{v}} \beta 4$ did cause a modest but significant decrease for single AP-evoked 
A

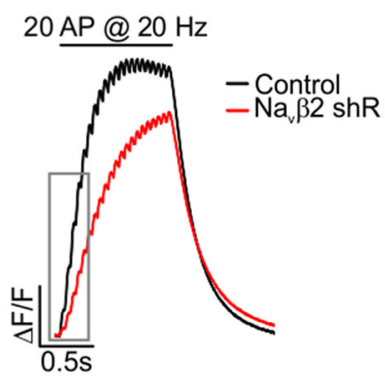

B

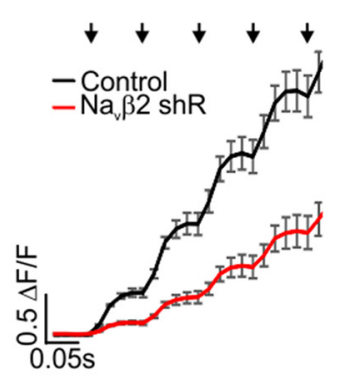

C

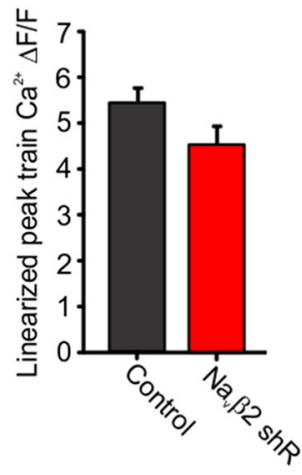

D

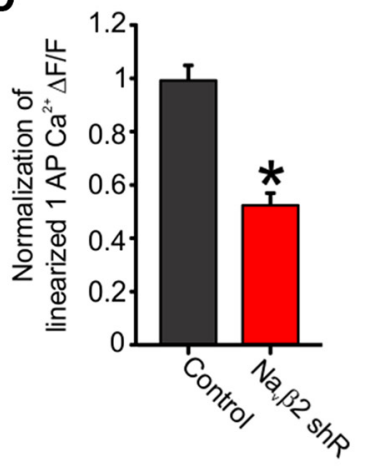

E

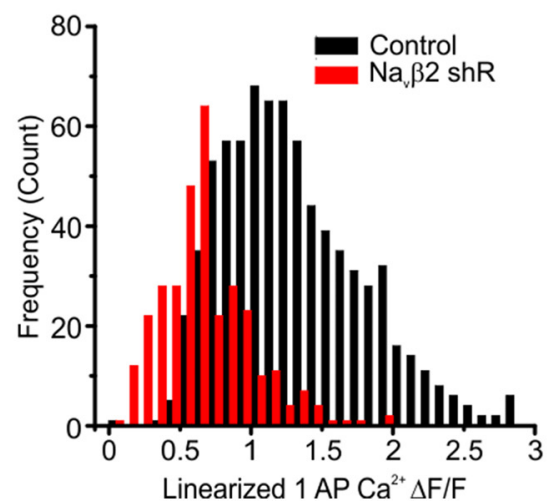

F

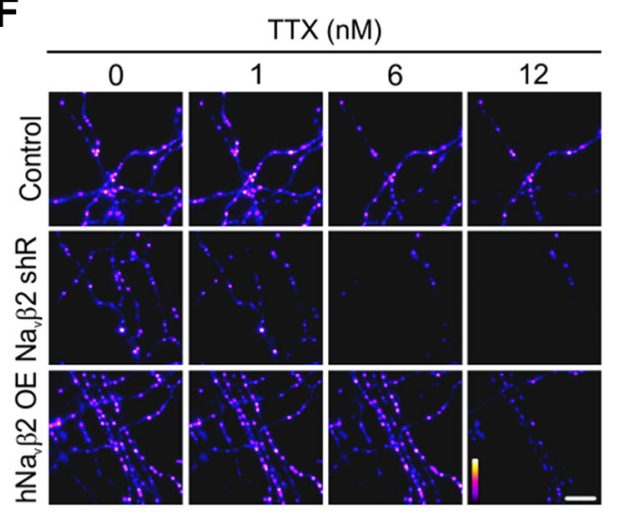

G

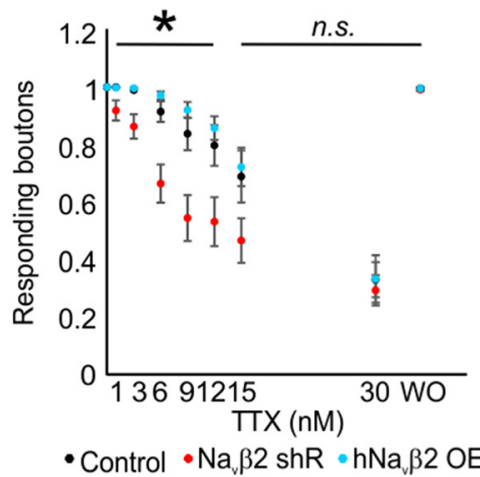

Figure 6. Presynaptic $\mathrm{Ca}^{2+}$ entry controlled by Na $\beta 2 \mathrm{~s} . \boldsymbol{A}$, Average SypGCaMP signals in response to trains of $20 \mathrm{AP}$ at $20 \mathrm{~Hz}$ of electrical stimulation. $\boldsymbol{B}$, Inset of Figure $2 A$. Each arrow (top) indicates successive individual AP stimuli. C, Average peak amplitude of $\mathrm{Ca}^{2+}$ transients evoked by trains ( $20 \mathrm{AP}$ at $\left.20 \mathrm{~Hz}\right)$ of electrical stimulation (Control, $n=22 ; \mathrm{Na}_{\mathrm{v}} \beta 2$ shRNA, $n=24$; $p=0.059)$. Each individual trial is the average of $25-35$ boutons from a single cell. $\boldsymbol{D}$, Linearized average $\mathrm{Ca}^{2+}$ transients evoked by single AP stimulation (Control, $n=22 ; \mathrm{Na}_{\mathrm{v}} \beta 2$ shRNA, $n=24$; $\left.{ }^{*} p=4.17{ }^{*} 10^{-9}\right)$. $\boldsymbol{E}$, Histogram of individual synaptic responses (SypGCaMP) from single AP stimulation from each condition. Peak $\mathrm{Ca}^{2+}$ influx level normalized to the first $\mathrm{Ca}^{2+}$ influx level (Control, $n=22$ cells and 763 boutons; $\mathrm{Na}_{\mathrm{v}} \beta 2$ shRNA, $n=12$ cells and 318 boutons). All values for $\mathrm{Ca}^{2+}$ have been linearized $(n=24) . F, \Delta F$ images obtained for trains of $20 \mathrm{AP}$ at $20 \mathrm{~Hz}$ stimulation with different concentrations of TTX from a SypGCaMP-transfected neurons' axonal field (Control, $n=13 ; \mathrm{Na}_{\mathrm{v}} \beta 2$ shRNA, $n=15 ; \mathrm{hNa} \mathrm{v}_{\mathrm{v}} \beta 20 \mathrm{E}, n=14$ ). G, Ratio of responsive boutons to $20 \mathrm{AP} \pm$ various concentrations of TTX compared with responsive boutons before application of TTX. WO, Washout. All fluorescence is shown at the same scale across images. Error bars indicate mean \pm SEM; ${ }^{*} p<0.05$, ANOVA with Tukey's post hoc comparisons.

$\mathrm{Ca}^{2+}$ influx $(28.5 \pm 8.3 \%$ reduction, $p<0.05, n=11$ cells; data not shown), although the exact degree of knock-down could not be quantified. Furthermore, the reduction of $\mathrm{Na}_{\mathrm{v}} \beta 2$ leads to significantly impaired AP activation of presynaptic terminals within specific branches of the axon. This was determined by all boutons within a branch remaining silent in terms of AP-evoked $\mathrm{Ca}^{2+}$ entry independent of AP generation at the axon initial segment.

Branch point failures are not the result of low AP amplitudes The decreased amplitude of the AP in $\mathrm{Na}_{\mathrm{v}} \beta 2$ shRNA-transfected neurons was reminiscent of the low-amplitude synaptic AP measured in cells overexpressing $\alpha 2 \delta \mathrm{Ca}^{2+}$ channel subunits, as described previously (Hoppa et al., 2014). We speculated that perhaps the decreased amplitude of the overall axonal AP in $\mathrm{Na}_{\mathrm{v}} \beta 2$ absent neurons could lead to branch point failures of APevoked $\mathrm{Ca}^{2+}$ entry independent of $\mathrm{Na}_{\mathrm{v}}$ subunits within branch points of the axon. Although the overexpression of $\alpha 2 \delta-1 \mathrm{Ca}^{2+}$ channel subunits did lead to a reduction in AP-initiated $\mathrm{Ca}^{2+}$ influx (Fig. 9A,B), as described previously (Hoppa et al., 2014), we could not observe any significant AP propagation defects from a simple lowering of AP amplitude. The ratio of boutons responding to electrical stimulation compared with high $\mathrm{K}^{+}$stimulation was $93.0 \pm 2.1 \%(p>0.1)$ using our SypGCaMP assay (Fig. 9C,D). We attribute this small but insignificant dip in responding boutons to some trouble with signal detection because "failures" were not connected within the branch and were simply a result of overall lower responses. These results indicate a unique role for the $\mathrm{Na}_{\mathrm{v}} \beta 2$ within specific regions of the axon for preventing AP propagation failures across all branch points of the axonal arborization that is independent of AP amplitude at presynaptic terminals.

\section{$\mathrm{Na}_{\mathrm{v}} \boldsymbol{\beta} 2$ is essential to maintaining $\mathrm{AP}$ propagation fidelity}

Our results suggested that $\mathrm{Na}_{\mathrm{v}} \beta 2$ provides subcellular tuning of the AP waveform across various branches of the unmyelinated axon to maintain AP propagation and ensure synaptic responses to AP firing. To avoid off target knock-down phenotypes, we wanted to rescue expression using an exogenous human $\mathrm{Na}_{\mathrm{v}} \beta 2$ $\left(\mathrm{hNa}_{\mathrm{v}} \beta 2\right)$. To ensure both efficient reduction of endogenous $\mathrm{Na}_{\mathrm{v}} \beta 2$ and rescue with an exogenous $\mathrm{hNa}_{\mathrm{v}} \beta 2$, we created two polycistronic expression vectors including a cytosolic mCherry marker to ensure sufficient expression of sgRNA and Cas9 and expression of exogenous $\mathrm{hNa}_{\mathrm{v}} \beta 2$ by linking it with SypGCaMP on each of the two bicistronic T2A expression vectors (Fig. 10A), as described previously for efficient polycistronic expression (Kim et al., 2011). This CRISPR InDel approach mimicked the shRNA phenotypes for impaired AP-driven synaptic function as measured by SypGCaMP (Fig. 10B). The impaired AP-driven $\mathrm{Ca}^{2+}$ entry in neurons with $\mathrm{Na}_{\mathrm{v}} \beta 2$ sgRNA for trains of stimulation (sgRNA alone; $70.5 \pm 4.6 \%$ of rescue, $p<0.05$ ) and for 
A
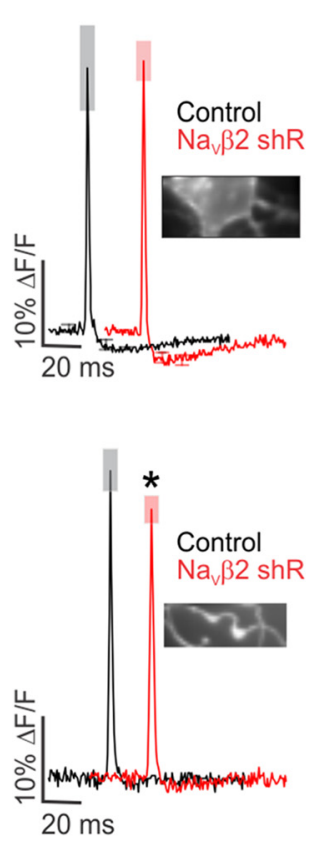

B

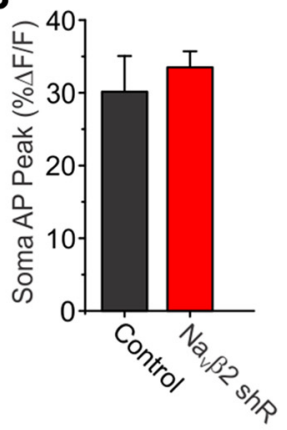

E

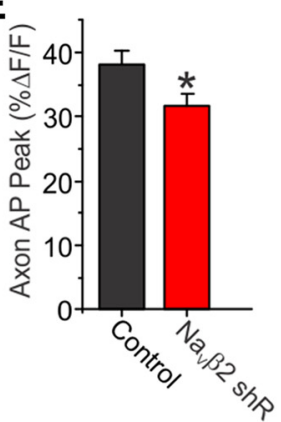

C

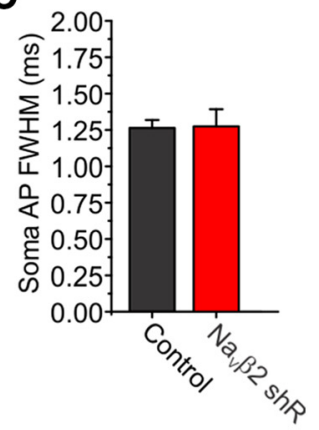

$F$

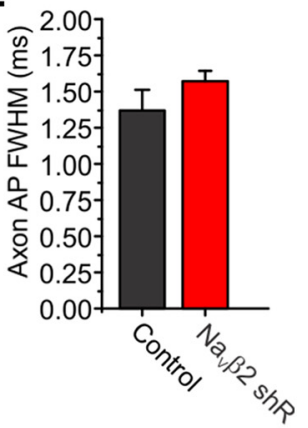

G

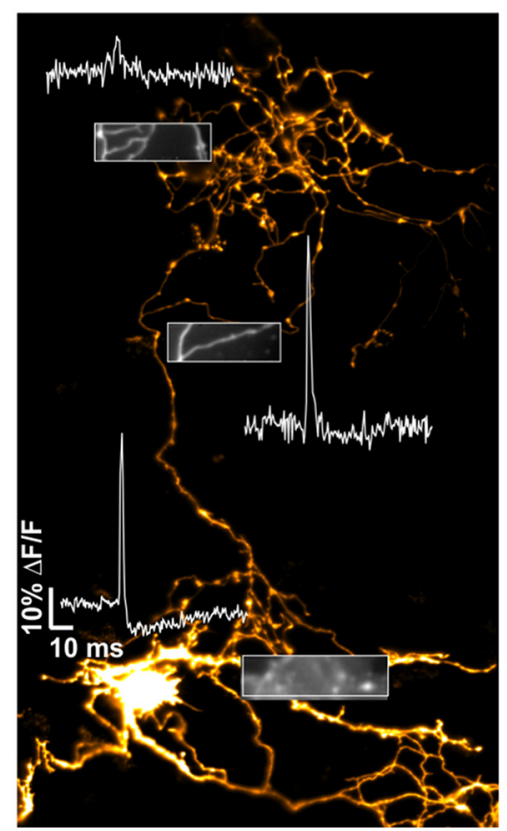

H

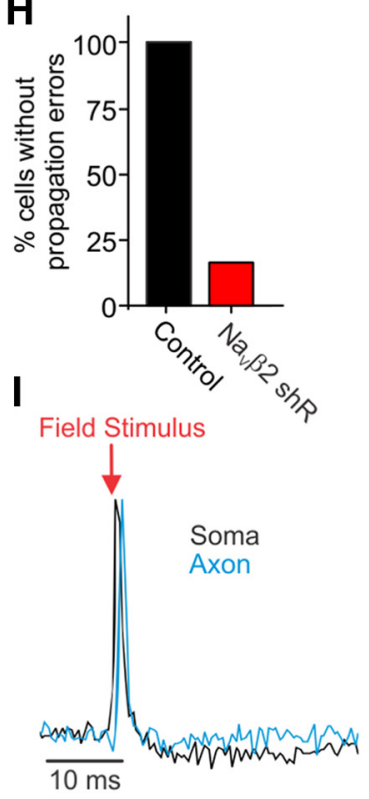

Figure 7. Optical measurements of AP waveforms in $\mathrm{Na}_{v} \beta 2$ deficient neurons. $A$, Average AP recorded from soma in hippocampal neuron expressing QuasAr in control (black) or $\mathrm{Na}_{\mathrm{v}} \beta 2$ shRNA (red)-transfected neurons. Representative image of QuasAr $\Delta$ F from soma shown in inset. $\boldsymbol{B}, \boldsymbol{C}$, Average amplitudes $(\boldsymbol{B})$ and FWHM $(\boldsymbol{C})$ of somatic AP waveforms as shown in $\boldsymbol{A}$ (Control, $n=8 ; \mathrm{Na}_{\mathrm{v}} \beta 2$ shRNA, $n=8$ ). $\boldsymbol{D}$, Average QuasAr measurements across control and $\mathrm{Na}_{\mathrm{v}} \beta 2$ shRNA-transfected axons. Representative image of axon/bouton QuasAr $\Delta F$ shown in inset. $\boldsymbol{E}, \boldsymbol{F}$, Average amplitudes $(\boldsymbol{E})$ and FWHM $(\boldsymbol{F})$ of axonal AP waveforms as shown in $\boldsymbol{D}$. Representative image of QuasAr $\Delta F$ from axon with en passant synapses shown in inset (Control, $n=$ $8 ; \mathrm{Na}_{\mathrm{v}} \beta 2$ shRNA, $n=8$ ). G, Montage of several fields (m0range fluorescence) from a dissociated hippocampal neuron expressing QuasAr-m0range with $\mathrm{Na}_{v} \beta 2$ shRNA. Inset images showing the soma (bottom) and branches (middle, top) of inherent QuasAr fluorescence. Representative AP recorded from the regions shown in each inset. Scale bar, $20 \mu \mathrm{m}$. $\boldsymbol{H}$, Cells displaying successful AP propagation across three branch points and soma (Control, $n=8 ; \mathrm{Na}_{v} \beta 2$ shRNA, $n=8$ ). I, Example recording of AP from a single cell at the soma (black) and axon (blue); note the delay of the AP recorded from the axon compared with the soma, as would be expected from orthodromic propagation from the initial segment of the axon.

single AP stimulation ( $s g R N A$ alone; $52.5 \pm 5.8 \%$ of rescue, $p<$ 0.05 ) was fully restored for both stimulations when rescued with $\mathrm{hNa}_{\mathrm{v}} \beta 2$ (Fig. 10C,D). Next, we tested overall AP-propagation efficiency by comparing the ratio of boutons that responded to 20

AP trains with those that responded to high- $\mathrm{K}^{+}$stimulation. We found that exogenous $\mathrm{hNa}_{\mathrm{v}} \beta 2$ expression restored APdriven $\mathrm{Ca}^{2+}$ entry in $98.9 \pm 0.8 \%$ of boutons compared with those elicited by high $\mathrm{K}^{+}$, whereas sgRNA knock-down alone found a significant $30 \%$ decrease in the ratio of boutons responding to AP stimulation (70.2 \pm 3.2\%; Fig. 10E,F). Again, these results for electrically induced $\mathrm{Ca}^{2+}$ entry were independent of the response to high- $\mathrm{K}^{+}$stimulation ( $p=0.245$; Fig. $10 G)$. These results are consistent with $\mathrm{Na}_{\mathrm{v}} \beta 2$ as a specific and powerful regulator of AP propagation across branch points in arborized unmyelinated axons.

\section{Discussion}

In this study, we used a combination of sensitive, genetically encoded $\mathrm{Ca}^{2+}$ and voltage indicators to examine the presynaptic AP in unmyelinated axons that form en passant boutons. We used cultured hippocampal neurons as a proxy for en passant synaptic terminals such as those commonly found in the cortex and hippocampus in vivo. We report larger than expected levels of heterogeneity in the shape of axonal AP waveform between individual branches of a single axonal arborization as measured by the optical voltage indicator QuasAr (Fig. 1), as well as the TTX sensitivity of AP-evoked $\mathrm{Ca}^{2+}$ entry (Fig. 2). Detailed optical analysis of axonal geometry revealed that axon diameter does not seem to be a critical factor in the electrical diversity of branch responses (Fig. 4). Over the course of the experiments, we uncovered a critical role of $\mathrm{Na}_{\mathrm{v}} \beta 2$ to modulate AP-evoked $\mathrm{Ca}^{2+}$ influx (Fig. 6), as well as maintenance of AP propagation (Fig. 8). The role of $\mathrm{Na}_{\mathrm{v}} \beta 2$ to ensure proper AP-evoked $\mathrm{Ca}^{2+}$ entry across an axonal arborization was independent of somatic AP generation (Fig. 7). Overall, these findings contribute to a growing importance in the computational complexity within unmyelinated segments of a single axon (Debanne et al., 2011) and molecular repertoires that control the local balances of $\mathrm{Na}_{\mathrm{v}}$ and $\mathrm{K}_{\mathrm{v}}$ to sculpt local membrane excitability. This view is opposed to a role for the axon of simply relaying a digital all-or-none signal from the hillock to all synapses; modeling the mammalian axon with cable theory alone supports a "nanophysiology" in neuronal subcompartments (Holcman and Yuste, 2015). Although our findings were made in cultured primary neurons due to their high optical accessibility, we believe that their reliability as a well studied model for presynaptic function will translate into understanding the presynaptic AP modulation in vivo. A collection of molecules have been identified to 
stabilize and enrich $\mathrm{Na}_{\mathrm{v}}$ activity to modulate AP signaling at axon initial segments and nodes of Ranvier, but, to our knowledge, this is one of the first unique molecular partners of $\mathrm{Na}_{\mathrm{v}}$ providing subcellular modulation of APs in unmyelinated axons.

\section{Subcellular physiology of $\mathrm{Na}_{\mathrm{v}} \beta 2$ in neurons}

$\mathrm{Na}_{\mathrm{v}} \mathrm{s}$ are composed of a large $(260 \mathrm{kDa})$ pore-forming $\alpha$ subunits encoded by nine genes and small $(36 \mathrm{kDa}) \beta$ subunits encoded by four genes, $S c n 1 b-S c n 4 b$ (Isom et al., 1992; Isom et al., 1995; Catterall et al., 2005). When purified from the brain, $\mathrm{Na}_{\mathrm{v}} \alpha$ s are found in complex with multiple $\mathrm{Na}_{\mathrm{v}} \beta \mathrm{s}$ (Brackenbury and Isom, 2011). Coexpression of $\mathrm{Na}_{\mathrm{v}} \alpha$ s with various $\mathrm{Na}_{\mathrm{v}} \beta \mathrm{s}$ display significant changes in $\mathrm{Na}_{\mathrm{v}}$ current density, voltage-dependent gating, and inactivation kinetics in heterologous cells (Isom et al., 1994). $\mathrm{Na}_{\mathrm{v}} \beta 2$-null mice have a reduced $\mathrm{Na}^{+}$current density measured from acutely dissociated neurons and optic nerve axons bundles; however, the conduction velocity and localization of channels within the node of Ranvier appears normal as measured from optic nerve bundles (Chen et al., 2002). These optic nerve fibers have been shown previously to be have resilient conductance even with minimal $\mathrm{Na}_{\mathrm{v}}$ concentrations in the neonatal state, so the role of $\mathrm{Na}_{\mathrm{v}} \beta 2$ may be less relevant in these mature small axon caliper neurons for successful saltatory conductance (Waxman et al., 1989). However, $\mathrm{Na}_{\mathrm{V}} \beta 2$-null mice do have unique protective axonal phenotypes, including a resistance to allodynia from axon ligation (Lopez-Santiago et al., 2006), as well as neurodegeneration in an experimental model of multiple sclerosis, a disease of demyelination (O’Malley et al., 2009). It is thought that enhanced $\mathrm{Na}^{+}$currents within the axon increase membrane excitability and underlie both of these maladies. Slight modulation $\mathrm{Na}^{+}$current component of the waveform during active propagation within unmyelinated axons and associated en passant synapses would potentially have a much greater impact on neural function, as modeled previously (Engel and Jonas, 2005). Our data demonstrate a decreased amplitude of axonal $\mathrm{AP}$ and reduced $\mathrm{Ca}^{2+}$ influx at synapses with acute knock-down of $\mathrm{Na}_{\mathrm{v}} \beta 2$ (Figs. 6 , 7) that would support a model in which the loss of $\mathrm{Na}_{\mathrm{v}} \beta 2$ would protect against enhancing $\mathrm{Na}^{+}$currents in unmyelinated sections of axon. Moreover, a functional role for the subunits in normally unmyelinated sections of axon was identified clearly (Figs. 7, 8). Our data cannot rule
A
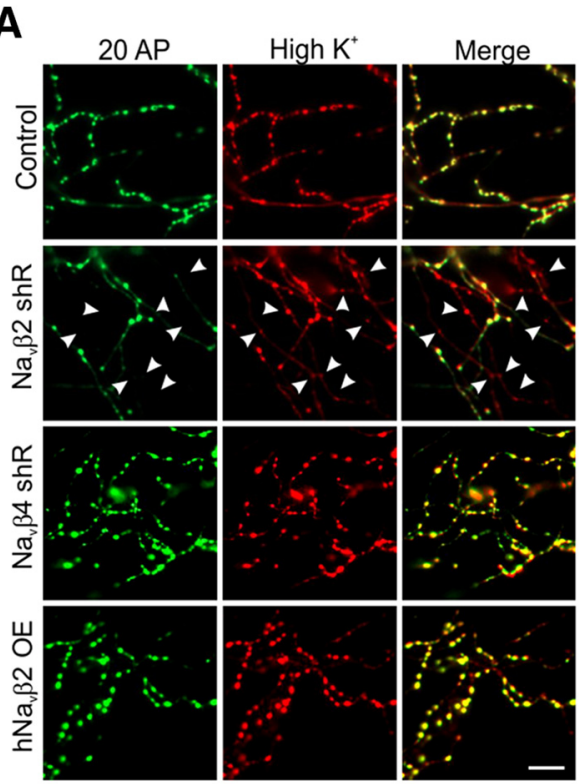

B

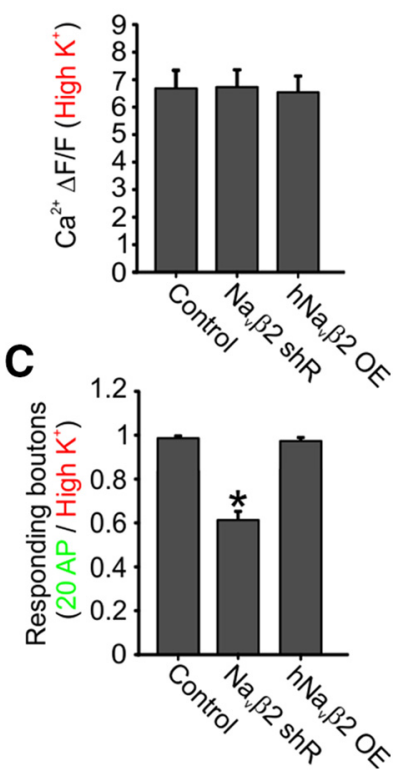

Figure 8. AP propagation failure at axon branches in $\mathrm{Na}_{\mathrm{v}} \beta 2$ deficient neurons. $\boldsymbol{A}$, Representative $\Delta F$ images obtained from SypGCaMP showing the increase in fluorescence during trains of $20 \mathrm{AP}$ at $20 \mathrm{~Hz}$ stimulation or high $\mathrm{K}^{+}$stimulation. White arrows indicate boutons responding to high- $\mathrm{K}^{+}$stimulation but not electrical stimulation. Scale bars, $20 \mu \mathrm{m}$. $\boldsymbol{B}$, Average of high- $\mathrm{K}^{+}$-driven bouton $\mathrm{Ca}^{2+}$ influx to measure functional $\mathrm{Ca}_{\mathrm{v}} \mathrm{s}$ densities in boutons. $\boldsymbol{C}$, Ratio of responsive boutons to $20 \mathrm{AP}$ to that of high- $\mathrm{K}^{+}$stimulation. For all experiments shown (Control, $n=12 ; \mathrm{Na}_{\mathrm{v}} \beta 2$ shRNA, $n=19$; $\mathrm{Na}_{\mathrm{v}} \beta 4$ shRNA, $n=9 ; \mathrm{hNa}_{\mathrm{v}} \beta 20 \mathrm{E}, n=9$ ). Error bars indicate mean $\pm \mathrm{SEM}$. ${ }^{*} p<0.05$, ANOVA with Tukey's post hoc comparisons.
A

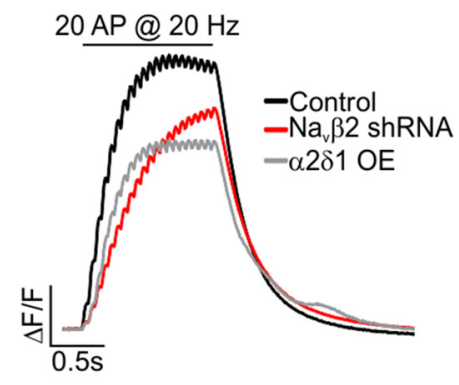

C

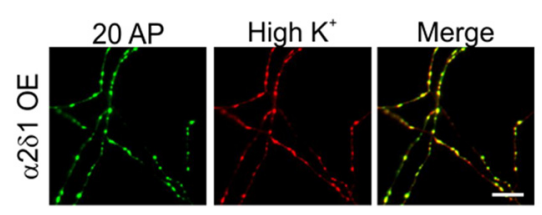

B
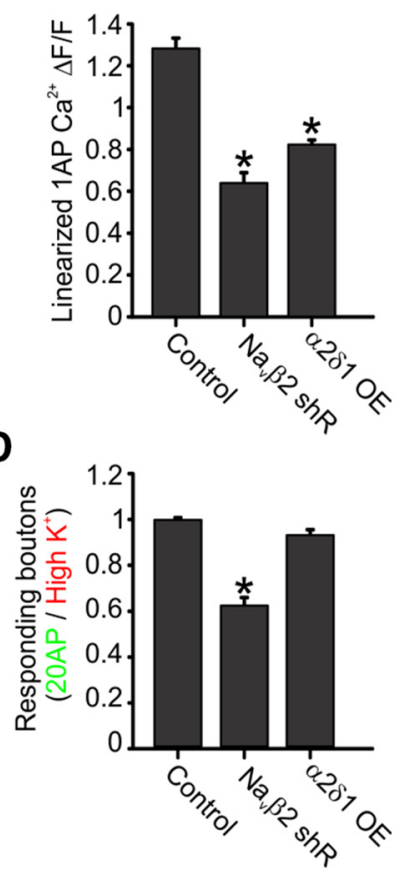

Figure 9. $\alpha 2 \delta$-1 overexpression induces lower AP amplitude but does not impair AP propagation. $\boldsymbol{A}$, Average SypGCaMP signals in response to trains of $20 \mathrm{AP}$ at $20 \mathrm{~Hz}$ electrical stimulation for all three conditions (control, $\mathrm{Na}_{\mathrm{v}} \beta 2$ shRNA, and $\alpha 2 \delta-10 \mathrm{E}$ neurons). $\boldsymbol{B}$, Linearized average $\mathrm{Ca}^{2+}$ transients evoked by single AP stimulation. $\boldsymbol{C}$, Representative $\Delta F$ images obtained from SypGCaMP during a $20 \mathrm{AP}$ train stimulation at $20 \mathrm{~Hz}$ or high $\mathrm{K}^{+}$stimulation. Scale bars, $20 \mu \mathrm{m}$. D, Ratio of responsive boutons to $20 \mathrm{AP}$ to that of high $\mathrm{K}^{+}$stimulation for all four conditions (control, Na $\beta 2$ shRNA, and $\alpha 2 \delta$-10E neurons; $n=12$ for control, $n=$ 20 for $\mathrm{Na}_{\mathrm{v}} \beta 2$ shRNA and $n=18$ for $\alpha 2 \delta$-10E). ${ }^{*} p<0.05$, ANOVA with Turkey's post hoc comparisons. (Control and Na $\beta 2$ shRNA were displayed previously in Fig. 5 but are displayed again here for clarity.) 
A

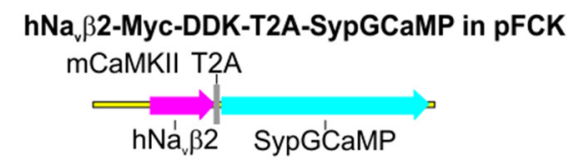

$\mathrm{Na}_{\mathrm{v}} \beta 2$ sgRNA in pU6_CBh-Cas9-T2A-mCherry $\mathrm{Na}_{\mathrm{v}} \beta 2$ sgRNA

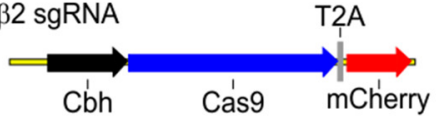

E
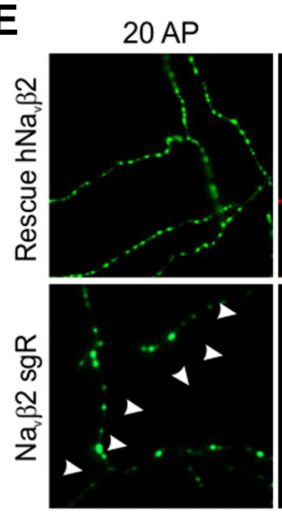

B

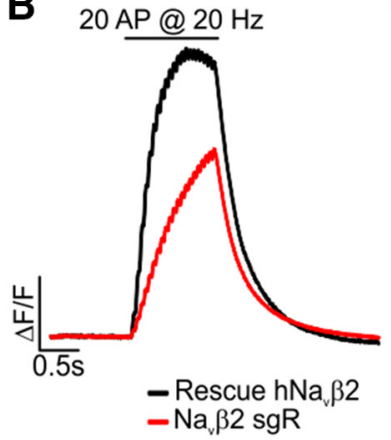

C

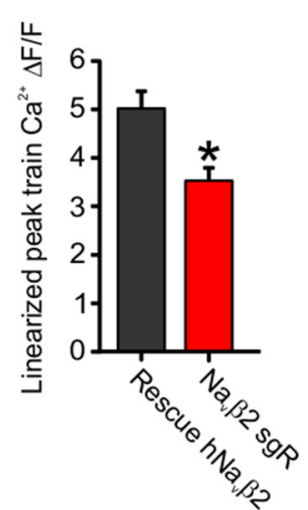

F

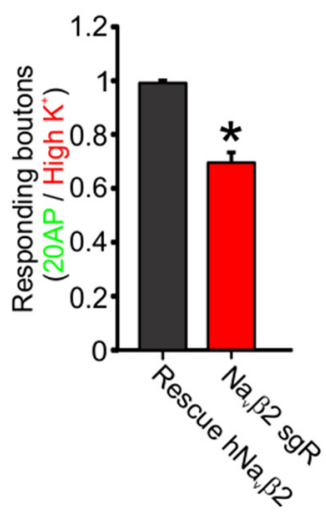

D

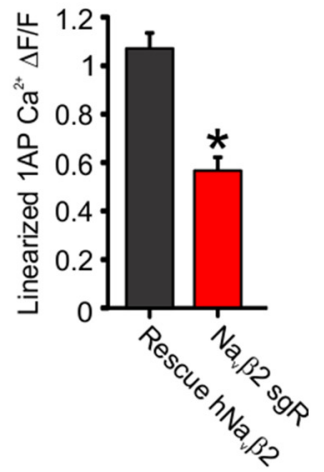

G

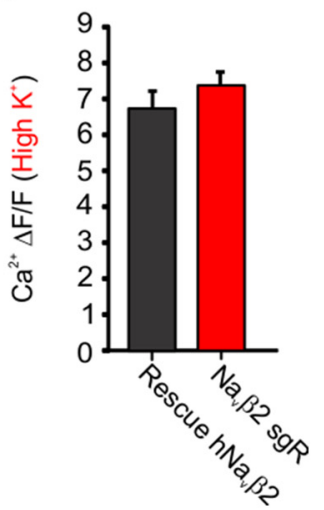

Figure 10. Human $\mathrm{Na}_{\mathrm{v}} \beta 2$ rescues single AP-driven $\mathrm{Ca}^{2+}$ influx deficits associated with $\mathrm{Na}_{\mathrm{v}} \beta 2$ reduction. $A$, Schematic describing the human $\mathrm{Na}_{\mathrm{v}} \beta 2$ construct linked to SypGCaMP via a T2A peptide (top). Schematic describing the construct that uses the hU6 promoter to drive $\mathrm{Na}_{\mathrm{v}} \beta 2$ sgRNA expression and the (Bh promoter to drive Cas9 and mCherry expression (bottom). $\boldsymbol{B}$, Average SypGCaMP signals in response to the trains of $20 \mathrm{AP}$ at $20 \mathrm{~Hz}$ stimulation. This trace is the average of 27 boutons from a single cell. C, Average of AP peak amplitudes of $\mathrm{Ca}^{2+}$ transients evoked by the trains of $20 \mathrm{AP}$ at $20 \mathrm{~Hz}$ stimulation (rescue, $n=16 ; \mathrm{Na}_{v} \beta 2 \mathrm{sgRNA}, n=20$ ). ${ }^{*} p=0.00064$, Student's $t$ test. $\boldsymbol{D}$, Average of linearized Ca ${ }^{2+}$ transients evoked by single AP electrical stimulation. ${ }^{*} p=6.8 * 10^{-6}$, Student's $t$ test. E, Representative images (SypGCaMP) of 20 AP-driven or high $\mathrm{K}^{+}$-induced presynaptic $\mathrm{Ca}^{2+}$ influx from boutons. Arrows indicate boutons responding to high $\mathrm{K}^{+}$stimulation, but not electrical stimulation. Scale bars, $20 \mu \mathrm{m}$. $\boldsymbol{F}$, Average $20 \mathrm{AP}$ stimulus-driven bouton Ca ${ }^{2+}$ influx (rescue, $n=17 ; \mathrm{Na}_{\mathrm{v}} \beta 2$ sgRNA, $n=24$ ). Shown is the ratio of responsive boutons to $20 \mathrm{AP}$ to that of $\mathrm{K}^{+}$solution. ${ }^{*} p=0.0074$, Student'st test. $G$, Average of high- $\mathrm{K}^{+}$-driven bouton $\mathrm{Ca}^{2+}$ influx to measure functional $\mathrm{Ca}_{\mathrm{v}} \mathrm{s}$ densities in boutons. Error bars indicate mean \pm SEM. $p=0.25$, Student's $t$ test.

out a possible role for $\mathrm{Na}_{\mathrm{v}} \beta 2$ in targeting or interacting with other ion channels such as $\mathrm{K}_{\mathrm{v}}$ s. Previous studies revealed that $\mathrm{Na}_{\mathrm{v}} \beta 1$ interacts with $\mathrm{K}_{\mathrm{v}} 1, \mathrm{~K}_{\mathrm{v}} 4$, and $\mathrm{K}_{\mathrm{v}} 7$ to enhance their activity during membrane depolarization (Marionneau et al., 2012; Nguyen et al., 2012). We do not think that $\mathrm{Na}_{\mathrm{v}} \beta 2$ follows this interaction model because the loss of $\mathrm{Na}_{\mathrm{v}} \beta 2$ caused the opposite response on our axonal APs, where they lost amplitude rather than gained. Furthermore, we also think the opposite role is unlikely because enhanced $\mathrm{K}_{\mathrm{v}}$ activity to decrease AP amplitude would also likely lead to a thinner AP FWHM, which we did not observe (Fig. 7). Based on this evidence of shorter and wider APs, we think that $\mathrm{Na}_{\mathrm{v}} \beta 2$ follows a more classic interaction with the $\mathrm{Na}_{\mathrm{v}} \alpha$ for surface trafficking and modulation of gating, which, due to the fine structure of the axon, is hard to parse experimentally. We can also not comment on whether axons contain heterogeneities in $\mathrm{Na}_{\mathrm{v}} 1.6$ and $\mathrm{Na}_{\mathrm{v}} 1.2 \alpha$-subunit levels because both channels are expressed in these cells with nearly identical sensitivities to TTX (Rosker et al., 2007). It is interesting to speculate that various combinations of $\mathrm{Na}_{\mathrm{v}} \alpha$ and $\mathrm{Na}_{\mathrm{v}} \beta$ have defined subcellular targets, not only within the axon, but also between myelinated and unmyelinated sections given their divergent roles in the nervous system. Both $\mathrm{Na}_{\mathrm{v}} \beta 1$ and $\mathrm{Na}_{\mathrm{v}} \beta 4$ have been found to enrich at the axon initial segment with potentially antagonistic roles in modulating excitability (Aman et al., 2009). Thus far, branch points have not been considered a subcellular signaling domain in the axons relevant to AP shape, but data from us and others (Rowan et al., 2016) point to further investigation of axon collateral heterogeneity in electrical signaling.

\section{Implications of heterogeneous axonal $\mathrm{Na}_{\mathrm{v}}$ activity for excitatory transmission}

AP propagation is generally quite reliable in terms of AP invasion throughout the axon (Cox et al., 2000; Apostolides et al., 2016). Detailed measurements of CA1 axons in slices using loose-seal recordings indicated reliable transmission of APs overall, but a heterogeneity between branches for transmission, especially at high-frequency stimulation (Raastad and Shepherd, 2003). Our results agree with a reliable transmission, but we speculate that this transmitted waveform is not uniform in its shape, which could be due in part to varied levels of $\mathrm{Na}_{\mathrm{v}}$ activity between branches of the axon based on optical measurement of the AP waveform (Fig. 1) and experimental evidence using TTX pharmacology (Fig. 2). What determines higher $\mathrm{Na}_{\mathrm{v}}$ activity within the unmyelinated axon? We were unable to image endogenous $\mathrm{Na}_{\mathrm{v}} \alpha$ isoforms or $\mathrm{Na}_{\mathrm{v}} \beta 2$ in such small-diameter axons due to the background of $\mathrm{Na}_{\mathrm{v}}$ in adjacent dendrites and potentially cocultured astrocytes. By geometry, the two biggest impedance barriers within the axon are the synaptic boutons and the axon branch points. Our physiological data did not find a correlation with the synaptic bouton densities or geometry within given branches that 
failed to propagate APs (Fig. 4); therefore, we believe the enrichment of $\mathrm{Na}_{\mathrm{v}}$ activity to be perisynaptic. Furthermore, our observance of failed propagation was usually traced to the start of a branching event (Fig. 3), indicating a specific role for the branch point to modulate AP propagation. We attribute this observed heterogeneity to molecular repertoires of channels and binding partners rather than morphology. Ultimately, small CNS neurons with bifurcating axons such as those in the hippocampal CA1 invade brain regions with different release properties despite identical cellular origins of the axon (Ali et al., 1998). These cells may use the AP as a flexible signal in which overall transmission is reliable, but the information it conveys to activate synaptic transmission varies at the level of branches or even synapses. Therefore, local axonal membrane excitability is not a red or green light for propagation, but a powerful subcellular lever controlling the spread of excitation in the brain. That being said, we do not believe AP shape to be the only lever controlling the variability of vesicle release probability. It is influenced by several factors, including vesicle pool dynamics, fusion machinery, as well as the properties of $\mathrm{Ca}_{\mathrm{v}} \mathrm{s}$ (Rizzoli and Betz, 2005; Catterall and Few, 2008; Südhof and Rothman, 2009; Körber and Kuner, 2016). The use of new tools to make detailed measurements of the AP in various preparations will improve our understanding of electrogenic properties of the axon to influence synaptic transmission going forward. Recent evidence using electron microscopy has shown that presynaptic $\mathrm{Ca}_{\mathrm{v}}$ density alone does not adequately explain heterogeneity in $\mathrm{Ca}^{2+}$ influx within axonal branches innervating various sections of the hippocampus, indicating a potentially critical role for the presynaptic AP waveform (Éltes et al., 2017). Given the critical role of en passant synapses and unmyelinated sections of axon in vivo within areas such as Schaffer collaterals in the hippocampus, these findings and further lines of inquiry could prove useful for specific molecular modulation of subcircuits in the brain.

\section{References}

Akin EJ, Solé L, Dib-Hajj SD, Waxman SG, Tamkun MM (2015) Preferential targeting of Nav1.6 voltage-gated $\mathrm{Na}+$ channels to the axon initial segment during development. PLoS One 10:e0124397. CrossRef Medline

Ali AB, Deuchars J, Pawelzik H, Thomson AM (1998) CA1 pyramidal to basket and bistratified cell EPSPs: dual intracellular recordings in rat hippocampal slices. J Physiol 507:201-217. CrossRef Medline

Aman TK, Grieco-Calub TM, Chen C, Rusconi R, Slat EA, Isom LL, Raman IM (2009) Regulation of persistent Na current by interactions between beta subunits of voltage-gated Na channels. J Neurosci 29:2027-2042. CrossRef Medline

Andersen P, Soleng AF, Raastad M (2000) The hippocampal lamella hypothesis revisited. Brain Res 886:165-171. CrossRef Medline

Apostolides PF, Milstein AD, Grienberger C, Bittner KC, Magee JC (2016) Axonal filtering allows reliable output during dendritic plateau-driven complex spiking in CA1 neurons. Neuron 89:770-783. CrossRef Medline

Ariel P, Hoppa MB, Ryan TA (2012) Intrinsic variability in Pv, RRP size, $\mathrm{Ca}(2+)$ channel repertoire, and presynaptic potentiation in individual synaptic boutons. Front Synaptic Neurosci 4:9. CrossRef Medline

Augustine GJ, Charlton MP, Smith SJ (1985) Calcium entry and transmitter release at voltage-clamped nerve terminals of squid. J Physiol 367:163181. CrossRef Medline

Bean BP (2007) The action potential in mammalian central neurons. Nat Rev Neurosci 8:451-465. CrossRef Medline

Bischofberger J, Geiger JR, Jonas P (2002) Timing and efficacy of Ca2+ channel activation in hippocampal mossy fiber boutons. J Neurosci 22: 10593-10602. Medline

Borst JG, Sakmann B (1999) Effect of changes in action potential shape on calcium currents and transmitter release in a calyx-type synapse of the rat auditory brainstem. Philos Trans R Soc Lond B Biol Sci 354:347-355. CrossRef Medline
Brackenbury WJ, Isom LL (2011) Na channel beta subunits: overachievers of the ion channel family. Front Pharmacol 2:53. CrossRef Medline

Catterall WA, Few AP (2008) Calcium channel regulation and presynaptic plasticity. Neuron 59:882-901. CrossRef Medline

Catterall WA, Goldin AL, Waxman SG (2005) International Union of Pharmacology. XLVII. Nomenclature and structure-function relationships of voltage-gated sodium channels. Pharmacol Rev 57:397-409. CrossRef Medline

Chen C, Bharucha V, Chen Y, Westenbroek RE, Brown A, Malhotra JD, Jones D, Avery C, Gillespie PJ 3rd, Kazen-Gillespie KA, Kazarinova-Noyes K, Shrager P, Saunders TL, Macdonald RL, Ransom BR, Scheuer T, Catterall WA, Isom LL (2002) Reduced sodium channel density, altered voltage dependence of inactivation, and increased susceptibility to seizures in mice lacking sodium channel beta 2-subunits. Proc Natl Acad Sci U S A 99:17072-17077. CrossRef Medline

Chen TW, Wardill TJ, Sun Y, Pulver SR, Renninger SL, Baohan A, Schreiter ER, Kerr RA, Orger MB, Jayaraman V, Looger LL, Svoboda K, Kim DS (2013) Ultrasensitive fluorescent proteins for imaging neuronal activity. Nature 499:295-300. CrossRef Medline

Cox CL, Denk W, Tank DW, Svoboda K (2000) Action potentials reliably invade axonal arbors of rat neocortical neurons. Proc Natl Acad Sci U S A 97:9724-9728. CrossRef Medline

Debanne D, Campanac E, Bialowas A, Carlier E, Alcaraz G (2011) Axon physiology. Physiol Rev 91:555-602. CrossRef Medline

Dodge FA Jr, Rahamimoff R (1967) Co-operative action a calcium ions in transmitter release at the neuromuscular junction. J Physiol 193:419432. CrossRef Medline

Éltes T, Kirizs T, Nusser Z, Holderith N (2017) Target Cell Type-Dependent Differences in Ca2 + Channel Function Underlie Distinct Release Probabilities at Hippocampal Glutamatergic Terminals. J Neurosci 37:19101924. CrossRef Medline

Engel D, Jonas P (2005) Presynaptic action potential amplification by voltage-gated $\mathrm{Na}+$ channels in hippocampal mossy fiber boutons. Neuron 45:405-417. CrossRef Medline

Ermolyuk YS, Alder FG, Henneberger C, Rusakov DA, Kullmann DM, Volynski KE (2012) Independent regulation of basal neurotransmitter release efficacy by variable $\mathrm{Ca}(2)+$ influx and bouton size at small central synapses. PLoS Biol 10:e1001396. CrossRef Medline

Hartshorne RP, Messner DJ, Coppersmith JC, Catterall WA (1982) The saxitoxin receptor of the sodium channel from rat brain. Evidence for two nonidentical beta subunits. J Biol Chem 257:13888-13891. Medline

Hochbaum DR et al. (2014) All-optical electrophysiology in mammalian neurons using engineered microbial rhodopsins. Nat Methods 11:825833. CrossRef Medline

Holcman D, Yuste R (2015) The new nanophysiology: regulation of ionic flow in neuronal subcompartments. Nat Rev Neurosci 16:685-692. CrossRef Medline

Hoppa MB, Lana B, Margas W, Dolphin AC, Ryan TA (2012a) alpha2delta expression sets presynaptic calcium channel abundance and release probability. Nature 486:122-125. CrossRef Medline

Hoppa MB, Jones E, Karanauskaite J, Ramracheya R, Braun M, Collins SC, Zhang Q, Clark A, Eliasson L, Genoud C, Macdonald PE, Monteith AG, Barg S, Galvanovskis J, Rorsman P (2012b) Multivesicular exocytosis in rat pancreatic beta cells. Diabetologia 55:1001-1012. CrossRef Medline

Hoppa MB, Gouzer G, Armbruster M, Ryan TA (2014) Control and plasticity of the presynaptic action potential waveform at small CNS nerve terminals. Neuron 84:778-789. CrossRef Medline

$\mathrm{Hu} \mathrm{H}$, Jonas $\mathrm{P}$ (2014) A supercritical density of $\mathrm{Na}(+)$ channels ensures fast signaling in GABAergic interneuron axons. Nat Neurosci 17:686-693. CrossRef Medline

Isom LL, De Jongh KS, Patton DE, Reber BF, Offord J, Charbonneau H, Walsh K, Goldin AL, Catterall WA (1992) Primary structure and functional expression of the beta 1 subunit of the rat brain sodium channel. Science 256:839-842. CrossRef Medline

Isom LL, De Jongh KS, Catterall WA (1994) Auxiliary subunits of voltagegated ion channels. Neuron 12:1183-1194. CrossRef Medline

Isom LL, Ragsdale DS, De Jongh KS, Westenbroek RE, Reber BF, Scheuer T, Catterall WA (1995) Structure and function of the beta 2 subunit of brain sodium channels, a transmembrane glycoprotein with a CAM motif. Cell 83:433-442. CrossRef Medline

Kawaguchi SY, Sakaba T (2015) Control of inhibitory synaptic outputs by 
low excitability of axon terminals revealed by direct recording. Neuron 85:1273-1288. CrossRef Medline

Kim JH, Lee SR, Li LH, Park HJ, Park JH, Lee KY, Kim MK, Shin BA, Choi SY (2011) High cleavage efficiency of a 2A peptide derived from porcine teschovirus-1 in human cell lines, zebrafish and mice. PLoS One 6:e18556. CrossRef Medline

Koester HJ, Sakmann B (2000) Calcium dynamics associated with action potentials in single nerve terminals of pyramidal cells in layer $2 / 3$ of the young rat neocortex. J Physiol 529:625-646. CrossRef Medline

Körber C, Kuner T (2016) Molecular Machines Regulating the Release Probability of Synaptic Vesicles at the Active Zone. Front Synaptic Neurosci 8:5. CrossRef Medline

Kralj JM, Douglass AD, Hochbaum DR, Maclaurin D, Cohen AE (2011) Optical recording of action potentials in mammalian neurons using a microbial rhodopsin. Nat Methods 9:90-95. CrossRef Medline

Leão RM, Kushmerick C, Pinaud R, Renden R, Li GL, Taschenberger H, Spirou G, Levinson SR, von Gersdorff H (2005) Presynaptic Na + channels: locus, development, and recovery from inactivation at a high-fidelity synapse. J Neurosci 25:3724-3738. CrossRef Medline

Li H, Foss SM, Dobryy YL, Park CK, Hires SA, Shaner NC, Tsien RY, Osborne LC, Voglmaier SM (2011) Concurrent imaging of synaptic vesicle recycling and calcium dynamics. Front Mol Neurosci 4:34. CrossRef Medline

Li L, Bischofberger J, Jonas P (2007) Differential gating and recruitment of P/Q-, N-, and R-type Ca2+ channels in hippocampal mossy fiber boutons. J Neurosci 27:13420-13429. CrossRef Medline

Lisman JE, Raghavachari S, Tsien RW (2007) The sequence of events that underlie quantal transmission at central glutamatergic synapses. Nat Rev Neurosci 8:597-609. CrossRef Medline

Lopez-Santiago LF, Pertin M, Morisod X, Chen C, Hong S, Wiley J, Decosterd I, Isom LL (2006) Sodium channel beta2 subunits regulate tetrodotoxin-sensitive sodium channels in small dorsal root ganglion neurons and modulate the response to pain. J Neurosci 26:7984-7994. CrossRef Medline

Lüscher HR, Shiner JS (1990) Simulation of action potential propagation in complex terminal arborizations. Biophys J 58:1389-1399. CrossRef Medline

Marionneau C, Carrasquillo Y, Norris AJ, Townsend RR, Isom LL, Link AJ, Nerbonne JM (2012) The sodium channel accessory subunit Navbetal regulates neuronal excitability through modulation of repolarizing voltagegated $\mathrm{K}(+)$ channels. J Neurosci 32:5716-5727. CrossRef Medline

Mishchenko Y, Hu T, Spacek J, Mendenhall J, Harris KM, Chklovskii DB (2010) Ultrastructural analysis of hippocampal neuropil from the connectomics perspective. Neuron 67:1009-1020. CrossRef Medline

Miyazaki $\mathrm{H}$ et al. (2014) Singular localization of sodium channel beta4 subunit in unmyelinated fibres and its role in the striatum. Nat Commun 5:5525. CrossRef Medline

Namadurai S, Yereddi NR, Cusdin FS, Huang CL, Chirgadze DY, Jackson AP (2015) A new look at sodium channel beta subunits. Open Biol 5:140192. CrossRef Medline

Nguyen HM, Miyazaki H, Hoshi N, Smith BJ, Nukina N, Goldin AL, Chandy KG (2012) Modulation of voltage-gated $\mathrm{K}+$ channels by the sodium channel betal subunit. Proc Natl Acad Sci U S A 109:18577-18582. CrossRef Medline

O'Malley HA, Shreiner AB, Chen GH, Huffnagle GB, Isom LL (2009) Loss of $\mathrm{Na}+$ channel beta 2 subunits is neuroprotective in a mouse model of multiple sclerosis. Mol Cell Neurosci 40:143-155. CrossRef Medline

Prakriya M, Mennerick S (2000) Selective depression of low-release probability excitatory synapses by sodium channel blockers. Neuron 26:671682. CrossRef Medline

Raastad M, Shepherd GM (2003) Single-axon action potentials in the rat hippocampal cortex. J Physiol 548:745-752. CrossRef Medline

Rama S, Zbili M, Bialowas A, Fronzaroli-Molinieres L, Ankri N, Carlier E, Marra V, Debanne D (2015) Presynaptic hyperpolarization induces a fast analogue modulation of spike-evoked transmission mediated by axonal sodium channels. Nat Commun 6:10163. CrossRef Medline

Rizzoli SO, Betz WJ (2005) Synaptic vesicle pools. Nat Rev Neurosci 6:5769. CrossRef Medline

Rosenmund C, Clements JD, Westbrook GL (1993) Nonuniform probability of glutamate release at a hippocampal synapse. Science 262:754-757. CrossRef Medline

Rosker C, Lohberger B, Hofer D, Steinecker B, Quasthoff S, Schreibmayer W (2007) The TTX metabolite 4,9-anhydro-TTX is a highly specific blocker of the $\mathrm{Na}(\mathrm{v} 1.6)$ voltage-dependent sodium channel. Am J Physiol Cell Physiol 293:C783-789. CrossRef Medline

Rowan MJ, Tranquil E, Christie JM (2014) Distinct Kv channel subtypes contribute to differences in spike signaling properties in the axon initial segment and presynaptic boutons of cerebellar interneurons. J Neurosci 34:6611-6623. CrossRef Medline

Rowan MJ, DelCanto G, Yu JJ, Kamasawa N, Christie JM (2016) SynapseLevel Determination of Action Potential Duration by $\mathrm{K}(+)$ Channel Clustering in Axons. Neuron 91:370-383. CrossRef Medline

Sabatini BL, Regehr WG (1997) Control of neurotransmitter release by presynaptic waveform at the granule cell to Purkinje cell synapse. J Neurosci 17:3425-3435. Medline

Siegelbaum SA, Camardo JS, Kandel ER (1982) Serotonin and cyclic AMP close single K+ channels in Aplysia sensory neurones. Nature 299:413417. CrossRef Medline

Südhof TC, Rothman JE (2009) Membrane fusion: grappling with SNARE and SM proteins. Science 323:474-477. CrossRef Medline

Waxman SG, Black JA, Kocsis JD, Ritchie JM (1989) Low density of sodium channels supports action potential conduction in axons of neonatal rat optic nerve. Proc Natl Acad Sci U S A 86:1406-1410. CrossRef Medline

Wimmer VC, Reid CA, Mitchell S, Richards KL, Scaf BB, Leaw BT, Hill EL, Royeck M, Horstmann MT, Cromer BA, Davies PJ, Xu R, Lerche H, Berkovic SF, Beck H, Petrou S (2010) Axon initial segment dysfunction in a mouse model of genetic epilepsy with febrile seizures plus. J Clin Invest 120:2661-2671. CrossRef Medline

Yu FH, Westenbroek RE, Silos-Santiago I, McCormick KA, Lawson D, Ge P, Ferriera H, Lilly J, DiStefano PS, Catterall WA, Scheuer T, Curtis R (2003) Sodium channel beta4, a new disulfide-linked auxiliary subunit with similarity to beta2. J Neurosci 23:7577-7585. Medline 